\title{
COVID-19: guaranteed Loans and Zombie Firms
}

\author{
Benedikt Zoller-Rydzek (D) * and Florian Keller ${ }^{\dagger}$
}

*ZHAW School of Management and Law, Theaterstrasse 17, 8400 Winterthur, Switzerland. E-mail: benedikt.zoller@zhaw.ch and ${ }^{\dagger}$ ZHAW School of Management and Law, Theaterstrasse 17, 8400 Winterthur, Switzerland. E-mail: florian.keller@zhaw.ch

\begin{abstract}
Based on a survey (7-13 April 2020) we evaluate the reaction of Swiss firms towards the COVID-19 crisis. Firms show little pro-active reactions towards the crisis, but decrease their business activities. The firms in the survey report that the decline in foreign demand is the single most important reason for their deteriorating business situation. Firms that faced a more difficult business situation before the crisis are affected more severely during the crisis. Moreover, we investigate the impact of the Swiss federal loan program (Bundeshilfe) on the business activities. To this end, we develop a stylized theoretical model of financially constrained heterogeneous firms. We find that policy makers face a trade-off between immediate higher unemployment rates and long-term higher public spending. The former arises from a combination of a too strong economic impact of the COVID-19 lockdown (demand drop) and too low levels of loans provided. Nevertheless, providing (too) high levels of loans to firms creates zombie firms that are going to default in the future leading to an increase in public spending. (JEL codes: D22, D25, D84, and G33)
\end{abstract}

Key words: COVID-19, expectations, firm behavior, financial constraints, zombie firms

\section{Introduction}

The COVID-19 crisis does not only represent great challenges to local healthcare systems, but also puts many companies and organizations to a hard test. The arising problems are numerous and often unprecedented. This implies that during the COVID-19 crisis firms face an existential threat and might often fight for the survival of their business. Policy makers face the most severe crisis since 1930s Great Depression. Common economic policy instruments are untested in this special situation, thus it becomes even more important to understand the firm-level behavior by using theoretical models and empirical analysis.

In this paper, we investigate the impact of the COVID-19 crisis on Swiss firms by combining empirical findings from the ZHAW managers survey with a stylized theoretical model. The contribution of the study is 2 -fold. First, we analyze the expectation and actions of firms during the crisis in detail. To this end, we also consider firm-level responses such as 
short-time work or state loans that could mitigate economic impact of the COVID-19 crisis on firms. Second, we develop a stylized model of financially constraint firms along the lines of Manova (2013) and Chaney (2016) that specifically focuses on guaranteed loans for firms by the (Swiss) government to support financially distressed firms during the crisis.

State guarantees and loans at very low interest rates are a common policy instrument among many countries around the world to provide liquidity to firms during the COVID-19 pandemic, for example Germany, France, and Italy provide substantial guarantee and loan programs. According to the OECD (2020) the volume of state loans and guarantees varies dramatically between countries-for example Sweden provides about US $\$ 320$ million $(0.06 \%$ of GDP) in state guarantees (covering only $70 \%$ of the firm's loan), but Germany offers more than US\$610 billion (about $15 \%$ of GDP) in guaranteed loans to its firms. Even developing countries such as Brazil, South Africa, or Thailand use public loan programs and allocate substantial resources, for example, Brazil's loan program has a volume of about $0.6 \%$ of its GDP. Switzerland is no exception and provides guarantees with a volume of US\$40 billion (about $6 \%$ of GDP) to its firms. Even the EU through the European Investment Bank Group will provide loans up to EUR 200 billion for companies with a focus on small and medium-sized enterprises. Considering the magnitude of financial resources mobilized during the COVID-19 crisis to support firms, it is crucial to understand the firm-level impact of this widely used policy instrument and to what extend it might distort the economy. In this regard Switzerland provides a very good case study for developed (Western) economies with well-functioning financial institutions.

We find that the COVID-19 crisis dramatically impacts Swiss firms: the perceived business situation deteriorates from 'Good' to 'Neutral' at the median between 2019 and the expected peak economic impact of the COVID-crisis. This is mainly driven by a strong decline of foreign demand. Moreover, firms that faced a less favorable pre-crisis business situation expect a much stronger impact of the COVID-19 crisis. This is consistent with the findings of Buchheim et al. (2020) for German firms. The Swiss firms in our survey expected the peak economic impact of the COVID-19 crisis by mid July 2020 and a return to a (new) normal situation by the end of 2020. Given this rather short-time horizon it is not a surprise that most firms are not changing their business model dramatically. In this sense the efforts to 'freeze' the Swiss economy seemed to have worked. Most of the observed firm reactions are aiming at keeping the business operating at a minimal costs, that is, using short-time work and guaranteed loans by the federal government. In the public opinion providing government loans at very favorable terms to private companies is often seen critical. These loans could distort the market mechanism and keep firms (artificially) alive, although their business situation would not allow it. Caballero et al. (2008) coined the term zombie firms for these kinds of firms, when analyzing the Japanese firms in the 1990s. ${ }^{1}$

Empirically, we find that the probability to take up these guaranteed loans increases with the perceived pre-crisis business situation, that is, firms that were doing well before the crisis are more likely to use the Swiss federal loans. This implies that the Swiss federal loan program is not creating zombie firms at a large scale, but some firms (with a worse

1 More recently, McGowan et al. $(2017,2018)$ have shown that the share of such companies (the zombie share) has increased significantly in the wake of the 2008 financial crisis across advanced economies. Thus, one might expect a similar situation during the COVID-19 crisis. 
pre-crisis business situation) might actually fear the over-indebtedness due to the additional loans.

We develop a stylized model of financially constraint firms that is consistent with these empirical findings. In the model policy makers simultaneously decide about the economic impact, that is, the level of (economic) lockdown measures, and the extent of guaranteed loans provided to firms. ${ }^{2}$ In a normative sense, both should be positively related: a more severe economic lockdown should be accompanied by higher levels of guaranteed loans. In addition, we find that policy makers face a trade-off between increasing unemployment during the crisis and higher public spending in the long-run. The latter is due to overindebted firms defaulting after the crisis and the government paying for the guaranteed loans. If guaranteed loans are under-supplied relative to the economic lockdown measures, firms will not be able to cover their fixed operational costs during the crisis and hence become insolvent leading to higher unemployment rates. Assuming that firms are not able to roll-over their debt, they would need a productivity gain in the future (relative to the market) to repay their debt. This creates a wedge between firms that were profitable before the crisis and firms that are able to repay their debt.

The paper is structured as follows. Section 2 briefly summarizes the related literature. The Swiss COVID-19 pandemic situation and the related policies are described in Section 3. In Section 4, we develop a model of financial constrained firms and their reaction during an economic downturn. Section 5 presents stylized facts (based on the ZHAW managers survey) about the economic impact of the COVID-19 crisis on Swiss firms. Moreover, we show that the key model predicts are consistent with the empirical findings for Swiss firms. Finally, Section 6 concludes.

\section{Literature}

The recent research in economics is focusing heavily on the economic impact of COVID19. Most of these analyses are theoretical and often have interdisciplinary aspects by combining standard epidemiological models (Kermack and McKendrick 1927; Ferguson et al. 2020) with macroeconomic models, see for example Eichenbaum et al. (2020) or Guerrieri et al. (2020) on the interplay epidemic and economics. While these papers take a macroeconomic perspective, others have focused more on the firm-level reactions. Bloom et al. (2019), Bartik et al. (2020), Brülhart et al. (2020), and Buchheim et al. (2020) look at firms' reaction towards COVID-19 in the UK, USA, Switzerland, and Germany, respectively. ${ }^{3}$ Buchheim et al. (2020) is one of the few studies looking at firm expectations, which are very important in a situation with increased uncertainty, see Altig et al. (2020), Binder (2020), and Dietrich et al. (2020) for individual expectations.

The policy responses which firms faced due to the COVID-19 pandemic differed dramatically between countries and even within countries, see Gentilini et al. (2020) and Hale et al. (2020). At this point almost all countries in the world have implemented some kind of measures (for individuals and firms) to limit the spread of the pandemic. Interestingly, even as these measures vary considerable between countries, it seems that they serve more as a coordination device than as restrictive measures. In this regard Maloney and Taskin (2020) 
show that the personal mobility in Sweden with almost no lockdown restrictions fell similarly to the mobility in the USA. Similarly, Bargain and Aminjonov (2020) provide evidence that regional differences might be based on the underlying regional social contract, that is, political trust at the local level. This is also linked to partisan politics, see Barrios and Hochberg (2020).

The two main economic policy instruments used during the crisis in Switzerland are shorttime work and guaranteed loans to firms, see Eichenauer and Sturm (2020). Short-time work should help to maintain employee and employer matches. Once a match is resolved unemployment can be very persistent and have a lasting negative impact on earnings of dismissed workers, see Hamermesh (1989), Gregory and Jukes (2001), and Burda and Mertens (2001). Moreover, the possible loss of firm-specific knowledge might lead to even more negative long-run effects as described by Pissarides (1992) and Edin and Gustavsson (2008). Short-time work has proved to be an effective tool to mitigate negative labor market effects during an economic crisis: Kopp and Siegenthaler (2018) show that this was specifically the case for Switzerland during and after the 2008 financial crisis. While short-time work is perceived rather positively, loans to struggling firms are often seen much more critical. It is argued that these loans could distort the market mechanism and keep firms (artificially) alive although their business situation would not allow it. These firms can be seen as zombie firms (Caballero et al. 2008). Zombie firms are in general less productive and might crowd out growth of more productive firms by locking resources, which Banerjee and Hofmann (2018) call congestion effects. They also find that zombie firms decrease employment growth.

\section{COVID-19 in Switzerland}

In this section, we characterize the COVID-19 situation before and during the survey. We also describe Swiss (economic) policies during the crisis.

Figure 1 shows the timeline of the COVID-19 pandemic in Switzerland. The official first case was reported on the 25 February 2020 in the canton of Ticino in the southern part of Switzerland. On the 28 February the Swiss federal government banned all events with more than 1000 people. As the pandemic proceeded with an increasing number of cases and COVID19 related death the Swiss government canceled all classes of educational establishments and forbid events with more than 100 persons (13 March 2020) and closed non-essential shops, bars and meeting places (16 March 2020). It also limited gatherings to five persons.

The survey was conducted shortly after the peak of the pandemic, that is, the number of new cases already started to decline and the number of daily deaths reached its maximum during the week of the survey. All economic lockdown measures were already in place and a great degree of uncertainty about further measures existed at the time. In general Switzerland took a more laissez-faire approach to the COVID-19 crisis, consistently ranking as one of the least restricted countries in the Oxford Government Response Tracker, see Hale et al. (2020). ${ }^{4}$ Still the economic impact of COVID-19 and its associated policy measures is expected to be significant. The Swiss Economic Institute forecasts that the Swiss GDP will decline by $5.1 \%$ in 2020 , see KOF (2020).

4 From a political economy stand point lockdown measures lead to a rally affect in which voters take more favorable views on the incumbent government (Blais et al. 2020). As the Swiss federal government traditionally consists of a multi-party alliance, the necessity to create rally effects by imposing (harder) lockdown measures might be more limited than in many other countries. 


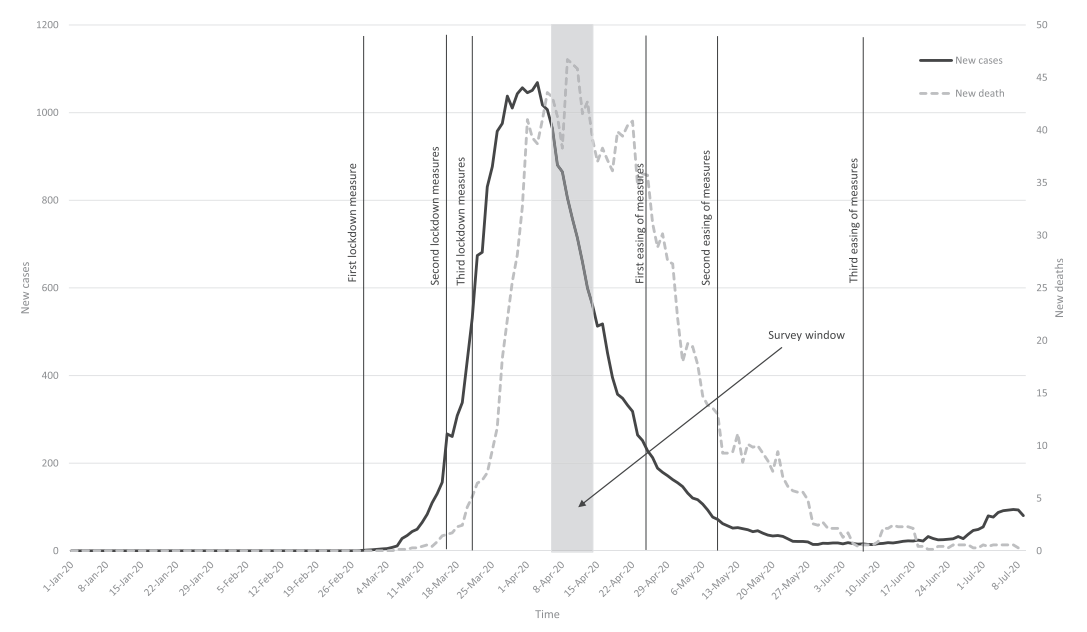

Figure 1. Timeline of COVID-19 cases and related deaths in Switzerland; 7-day moving average.

As many other countries Switzerland supported firms by providing liquidity in terms of loans to small and medium sized firms, see Eichenauer and Sturm (2020). Specifically, the loans to the firms were guaranteed by the Swiss central government up to CHF 500,000 (approx. US\$500,000), hence no collateral were needed. ${ }^{5}$ Firms simply applied for the guaranteed loans via their local bank, which also paid out the loan.

Loans were in general interest free and associated with minimal administrative burden. They were almost immediately granted and paid out, sometimes within hours after loan application. Thus, the Swiss banks took more of an intermediary role to distribute loans to firms, as these loans implied no risk for the local banks, that is, the credit contract is fully enforceable for the local bank as the federal government guarantees the loan.

Between 26 March 2020, when the loan program started, and 1 May 2020 banks provided 117,000 loans with a total volume of over CHF 16 billion (approx. US\$16 billion), see Eichenauer and Sturm (2020). Almost $80 \%$ of these loans were granted during the first 2 weeks, that is, the time immediate before the survey started.

In addition, the Swiss federal government used short-time work to avoid mass layoffs of firms. Short-time work allowed firms to temporarily reduce the working hours of its employees, while the Swiss unemployment insurance reimbursed the employee for up to $80 \%$ of the lost wage income.

The Swiss central government also allowed a postponement of firms' social insurance contribution and other taxes (VAT, import duties, etc.), thus implicitly provided more liquidity to firms during the crisis. Similarly, many cantons and municipalities allowed a deferment of profit tax payments at lower or no penalty interest. For example firms in the canton of Zurich could delay their tax payments up to 120 days and the penalty interest for further delays was reduced from $4.5 \%$ to $0.25 \%$.

Especially during the first months of the pandemic the Swiss central government played a mayor role in determining the policy responses. On 16 March 2020 the Swiss government declared an extraordinary situation which gave the central government the right to

5 The Swiss policy actually states that the loan cannot exceed $10 \%$ of firms total revenues, but loans below CHF 500,000 are granted with a minimal administrative burden. 
implement common policy measures at the state (canton) level. This state lasted until 19 June 2020. Thus, during this period general policies with regard to the COVID-19 pandemic (e.g. opening of shops and gathering limits) varied very little between the cantons.

\section{Model}

In this section, we develop a simple model of financially constrained firms. In terms of the proposed theoretical model, we follow closely Manova (2013) and Chaney (2016), but adjust their models to a country in autarky and the Swiss institutional setup. Specifically, we adapt the standard model of Manova (2013) to the aforementioned setting of Swiss federal loan program for firms during the COVID-19 crisis, that is, interest free loans without any collaterals.

In our model we consider three periods: (i) a pre-crisis period, which we take as benchmark, (ii) a crisis period, in which the demand for goods has dropped relative to the benchmark period, and (iii) a post-crisis or 'new normal' period, in which demand for goods has return to previous levels. ${ }^{6}$ Firms are heterogeneous as in Chaney (2008) version of the Melitz (2003) heterogeneous firms model. ${ }^{7}$

We rely on three main assumptions throughout the stylized model. First, the economic downturn due to COVID-19 is caused by a decline of demand and is not a supply shock. This is broadly consistent with Baqaee and Farhi (2020) and Guerrieri et al. (2020) who show that an initial supply shock can trigger a demand shock that is much bigger than the initial shock itself. Yet the increased uncertainty during the crisis might have caused a direct demand shock, see Leduc and Liu (2020). Second, while the demand during the crisis is lower for all firms in our model, the demand after the crisis will be equal to the demand before the crisis. This is related to the dramatic increase in uncertainty during the COVID-19 pandemic, see Altig et al. (2020). Firms and managers have never experienced a comparable economic shock. In the light of the uncertainty assuming a naive forecasting approach seems a reasonable assumption, that is, the new normal demand levels will be the same as before the crisis. This assumption could be relaxed, but this would introduce a wide variety of different scenarios to the model that add very little in terms of the model intuition. Third, firms that at any point in time are not able to finance their fixed operational costs are insolvent and hence bankrupt. In this case a firm will not take up any additional credit to partially cover its fixed costs. This assumption is in line with Swiss bankruptcy laws, that is, knowingly worsen the over-indebtedness of the firm makes the person liable (even with their private wealth and income).

\subsection{Utility}

The representative individual in the economy has an upper tier Cobb-Douglas utility function with share parameter $\lambda$. At the lower level the representative individual has CES (constant elasticity of substitution) preferences over a continuum of goods, $q(\omega)$, within the

6 As the credit does not bear any interest rate, we assume that the intertemporal discount rate is zero, which simplifies the model considerably.

7 The Chaney (2008) model offers a great simplification to analyze the extensive margin adjustments, without fully considering wage adjustments. 
set of goods $\Omega$, and a linear utility over a homogeneous good $q_{0}$ produced in an outside sector. This outside good, used as the numeraire, is produced under constant returns to scale. Thus, the individual utility is given by

$$
u=q_{0}^{1-\lambda_{j}}\left(\int_{\omega \in \Omega} q(\omega)^{\frac{\epsilon-1}{\epsilon}} d \omega\right)^{\lambda_{j} \frac{\epsilon}{\epsilon-1}}
$$

where $\epsilon>1$ is the constant elasticity of substitution. We use the upper tier Cobb-Douglas share parameter, $\lambda_{j}$, to introduce a demand shock in our model. $\lambda_{j}$ can be seen as a (relative) demand shifter for all differentiated goods. We assume that $0<\lambda_{C} \leq \lambda_{N}=\lambda_{B}<1$, where $j=B$ indicates before crisis values, $j=C$ indicates the values during the economic downturn, and $j=N$ after crisis (new normal) values. The pre- and post-crisis demand shifters are equal by assumption. Alternatively, we could use also an exogenous preference parameter within the CES utility function, which varies between all goods in the set $\omega$. Using the exogenous preference shifter within the CES sub-utility function is idiosyncratic to a productivity shock for the firm producing the respective variety. In this model we aim at modeling a demand side shock and hence the upper tier utility share parameter is more appropriate. Changes in the share parameter reflect shifts of the individual expenditures towards or away from the differentiated goods. ${ }^{8}$ We use only a two sector model and thus do not differentiate between different sectors, see Anderson and Yoto (2010) or Gopinath et al. (2014) for examples of multi-sector models. Including multiple sectors would only complicate the stylized model without adding much more intuition to the mechanism. Given that the upper-tier share parameter $\lambda$ governs the distribution of the demand it does not matter for the individual firm if the demand in its own sector shifts towards a generic homogeneous outside sector or any other (differentiated) sector.

The representative individual maximizes her CES sub-utility subject to the (residual) budget constraint

$$
\lambda_{j} Y=\int_{\omega \in \Omega} p(\omega) q(\omega) d \omega
$$

where $Y$ are the expenditures of the representative individual and $p(\omega)$ is the price of a good $\omega$. The demand for a good $q\left(\omega, \lambda_{j}\right)$ is given by

$$
q_{j}\left(\omega, \lambda_{j}\right)=\frac{p(\omega)^{-\epsilon} \lambda_{j} Y}{P^{1-\epsilon}}
$$

where

$$
P=\left(\int_{\omega \in \Omega} p(\omega)^{1-\epsilon} d \omega\right)^{\frac{1}{1-\epsilon}},
$$

is the CES price index, which all firms and individuals take as given.

8 Individuals might reduce their consumption of certain goods but increase others, i.e., travelling for vacation vs. buying a new computer. 


\subsection{Firms}

A firm producing a variety $\omega$ faces fixed costs $f$ that are re-occurring each period, see Chaney (2008). Firms are heterogeneous in terms of their productivity, $a$, which is drawn from a known cumulative distribution function $G(a)$ with support $0<a_{L}$. As $a$ is drawn from a continues function and each firm produces exactly one specific good, we can replace the good or firm indicator $\omega$ by the firm productivity $a$ that is uniquely identifying the firm and product. Producing one unit good $\omega \operatorname{costs} c / a$, where $c>0$ is the cost of a costminimizing bundle of inputs. The profits of a firm $a$ in any of the three considered periods $j=B, C, N$ are given by

$$
\pi_{j}(a)=p(a) q\left(a, \lambda_{j}\right)-q\left(a, \lambda_{j}\right) \frac{c}{a}-f+K_{j}
$$

where $K_{j}$ indicates the credit taken up or repaid. Specifically, $K_{N}=-K_{C}$ corresponds to the repayment of the credit with zero interest rate in the new normal. We assume $K_{B}=0$, that is, before the crisis firms are not using any credit. This assumption greatly simplifies the model. Allowing firm-specific pre-crisis debt levels introduces much more heterogeneity to the model, that is, firms will be heterogeneous in terms of productivity and fixed costs (due to the repayment of existing loans). Ultimately this will make the model less tractable. ${ }^{9}$

Firms are optimizing their profits considering the demand for goods (derived from the CES utility function) in Equation (3), while taking the price index in Equation (4) as given. Thus, the optimal price of a good provided by firm $a$ is given by

$$
p(a)=\frac{1}{\alpha} \frac{c}{a}
$$

where $\alpha=(\epsilon-1) / \epsilon$. Equation (6) gives the standard constant markup over marginal costs and is independent of the actual economic situation $\lambda_{j}$.

We assume that there is a maximum take up of credits, $K_{C} \leq M<f .{ }^{10}$

Firms can only borrow the amount necessary to cover their fixed costs and not finance any variable costs. This implies that during crisis there exists a cutoff productivity $\bar{a}_{C}>0$ for which $\pi_{C}\left(\bar{a}_{C}\right)=0$ given the maximum take up $K_{c}=M$. Firms with a lower productivity draw will not have enough earnings and credit available to them to cover their fixed costs in this period. We refer to this cutoff as the debt constraint.

9 Brülhart et al. (2020) show that among Swiss self-employed there is a higher propensity to take up federal loans during the crisis if the firm has already non-COVID-19 loans. This effect might arise from two firm characteristics. Usually banks assess loan applications and the ability to repay the loan before providing the loan to the firm. This implies that only firms that the bank believed to be able to repay the loan will receive a loan. Thus, some firms which have already loans were likely to be in a better (economic) situation before the crisis than some firms without loans. Second, existing loans implicitly increase fixed costs due to their current repayment plans. Intuitively, firms with higher fixed costs need to take up loans earlier as any reduction in sales has more severe effects relative to the fixed costs component.

10 The Swiss federal loan program allows firms to take up higher levels of credit, but in this case they would need to provide collateral assets. For simplicity we assume that firms are not able take up debt higher than the maximum $M$. 
Using the zero-profit condition, $\pi_{C}\left(\bar{a}_{C}\right)=0$, yields the cutoff $\bar{a}_{C}$ for firms to survive the crisis by using the maximum available credit $M$. This cutoff is given by

$$
\bar{a}_{C}=(f-M)^{\frac{1}{\epsilon-1}}\left(\frac{\epsilon}{\lambda_{C}}\right)^{\frac{1}{\epsilon-1}} Y^{\frac{1}{1-\epsilon}} \frac{\epsilon}{\epsilon-1} \frac{1}{P_{C}} c .
$$

Given the cutoff productivity and the following distribution of prices, the crisis price index $P_{C}\left(\bar{a}_{C}\right)$ can be determined analogously to Chaney (2008), see Appendix A for more details.

Next, we consider the firms that do not need to take up any debt during the crisis to ensure their survival, that is, there profits are non-negative during the crisis. In this case $\pi_{C}\left(\tilde{a}_{C}\right)=0$ with $K_{C}=0$ defines the viability cutoff for firms during the crisis, which we denote as $\tilde{a}_{C}$. Similarly, $\pi_{B}\left(\tilde{a}_{B}\right)=0$ with $K_{B}=0$ defines the viable firm before the crisis, and $\pi_{N}\left(\tilde{a}_{N}\right)=0$ with $K_{N}=0$ defines the viable firm in the new normal. The three cutoffs are given by

$$
\tilde{a}_{j}=f^{\frac{1}{\epsilon-1}}\left(\frac{\epsilon}{\lambda_{j}}\right)^{\frac{1}{\epsilon-1}} Y^{\frac{1}{1-\epsilon}} \frac{\epsilon}{\epsilon-1} \frac{1}{P_{j}} c \quad \forall j=B, C, N
$$

If a firm did take on any debt during the crisis, it has to repay it during the new normal period. A firm can afford to do so, if after repaying its debt it still has non-negative profits, that is, $\pi_{N}(a) \geq 0 .{ }^{11}$ Notice that the amount of credit a firm would take up during the crisis can be written as

$$
K_{C}^{\star}(a)=\max \left(0, \min \left(f-p(a) q\left(a, \lambda_{C}\right)+q\left(a, \lambda_{C}\right) \frac{c}{a}, M\right)\right) \quad \forall a \geq \bar{a}_{C}
$$

After substituting the optimal prices and quantities in Equation (9) the optimal credit take up during the crisis is given by

$$
K_{C}^{\star}(a)=\max \left(0, \min \left(f-\left(\frac{\epsilon-1}{\epsilon} a P_{C}\right)^{\epsilon-1} \frac{Y \lambda_{C}}{\epsilon}, M\right)\right) \quad \forall a \geq \bar{a}_{C} .
$$

Using that $K_{N}(a)=-K_{C}(a)$ we can re-write the after-crisis profits for firms that took up any debt as

$$
\pi_{N}\left(a, \lambda_{N}\right)=p(a) q\left(a, \lambda_{N}\right)-q\left(a, \lambda_{N}\right) \frac{c}{a}+p(a) q\left(a, \lambda_{C}\right)-q\left(a, \lambda_{C}\right) \frac{c}{a}-2 f \quad \forall a \geq \bar{a}_{C} .
$$

Only if $\pi_{N}(a) \geq 0$ a firm will be able to repay the debt after the crisis. The profits of firms that did not take up any debt during the crisis are given by Equation (5) with $K_{N}=K_{C}=0$. The cutoff condition to repay the debt is given by

We assume that the debt cannot be rolled over and unless repaid in full the firm will have to leave the market. 


$$
\pi\left(\bar{a}_{N}, \lambda_{N}\right)=\left(\frac{c}{\bar{a}_{N}}\right)^{1-\epsilon} \frac{1}{\epsilon}\left(\frac{\epsilon}{\epsilon-1}\right)^{1-\epsilon} Y\left(\frac{\lambda_{N}}{P_{N}^{1-\epsilon}}+\frac{\lambda_{C}}{P_{C}^{1-\epsilon}}\right)-2 f=0
$$

We refer to this as repayment constraint. Equation (12) can be solved for the new normal repayment cutoff $\bar{a}_{N}$ and the after-crisis price index $P_{N}$ can be derived. The repayment cutoff is given by

$$
\bar{a}_{N}=(2 f)^{\frac{1}{\epsilon-1}} \epsilon^{\frac{1}{\epsilon-1}} \frac{\epsilon}{\epsilon-1} Y^{\frac{1}{1-\epsilon}}\left(\frac{\lambda_{N}}{P_{N}^{1-\epsilon}}+\frac{\lambda_{C}}{P_{C}^{1-\epsilon}}\right)^{\frac{1}{1-\epsilon}} c .
$$

As $\lambda_{N}=\lambda_{B}$, the cutoff of a firm that is able to repay its debt is $\bar{a}_{N} \geq \tilde{a}_{B}$. Intuitively, the debt carried on from the crisis, increase the necessary sales or profits of the firm to repay the debt above the pre-crisis viability threshold. This creates a productivity wedge between firms that are able to repay their debt and firms that could survive the economic downturn using the Swiss federal loan program. It is this wedge that creates zombie firms.

Note that the viability cutoff in the new normal is different from the repayment cutoff, as the former only considers if a firm is able to cover its current fixed costs, but excludes any debt repayments. Given a positive debt level the following relationship can be established: $\bar{a}_{N}>\tilde{a}_{N}$. A post-crisis viable firm might not be able to repay its debt. Given that $\lambda_{N}=\lambda_{B}$ the viability cutoffs must be equal as well, that is, $\tilde{a}_{N}=\tilde{a}_{B} \cdot{ }^{12}$

\subsection{The good, the zombies and the ones left behind}

We have to distinguish three cases depending on the relationship of different productivity cutoffs. In the first case, we consider $\bar{a}_{N}>\bar{a}_{C} \geq \tilde{a}_{N}$, that is, the repayment constraint is binding for the firm, but not all viable firms have access to sufficient loans to survive the crisis. In the second case $\bar{a}_{N}>\tilde{a}_{N} \geq \bar{a}_{C}$ all viable firms are able to take up debt to survive the crisis. In the last case, the debt constraint is binding and hence $\bar{a}_{C}>\bar{a}_{N}>\tilde{a}_{N}$. We assume that firms will take up the guaranteed credit unless the debt constraint becomes binding, that is, even the maximum amount of credit would not be sufficient to ensure the survival of the firm during the crisis. If a firm survives the crisis, it needs the resources to repay its debt, otherwise it would have to default. Last, we assume that the viability cutoff during the crisis $\tilde{a}_{C}>\max \left(\bar{a}_{j}\right)$, that is, the economic downturn of the crisis makes it necessary for (some) firms to take up loans to survive the crisis.

A priori it is not clear which case is relevant for the economy, thus we will analyze all cases and derive their policy implications. Figure 2 shows the cutoffs and the resulting four firm types for all cases.

Recall that we assumed the viability cutoffs before and after the crisis to be equal, but lower than during the crisis, that is, $\tilde{a}_{B}=\tilde{a}_{N}<\tilde{a}_{C}$. Thus, all firms that can be observed during the crisis will have a productivity level of at least $\tilde{a}_{N}$, all other firms will not be in the market.

Case 1: $\bar{a}_{N}>\bar{a}_{C}>\tilde{a}_{N}$

In this scenario the repayment condition is the strictest. Three types of firms will be present in this case. 
Case 1: $\bar{a}_{N}>\bar{a}_{C}>\tilde{a}_{N}$

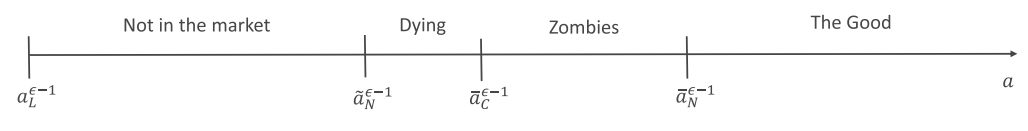

Case 2: $\bar{a}_{N}>\tilde{a}_{N}>\bar{a}_{C}$



Case 3: $\bar{a}_{C}>\bar{a}_{N}>\tilde{a}_{N}$

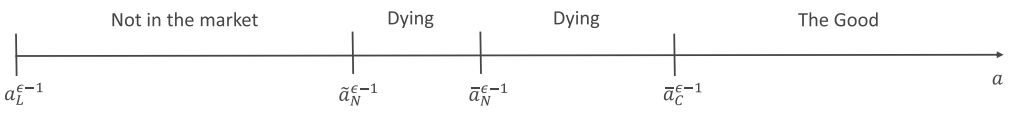

Figure 2. This figure plots the different firm types based on their productivity and the relationship of cutoffs of the debt, repayment constraints, and viability condition.

The good: $a \geq \max \left(\bar{a}_{N}, \bar{a}_{C}\right)$

Given the high productivity level of the firm (low costs), the maximum amount of credit available to the firm is sufficient to deal with the negative impact of the crisis and the firm will either not need any credit or be able to repay all the debt after the crisis. These firms use the guaranteed credit as indented. Within the good, there will be some firms with a productivity $a>\tilde{a}_{C}$ that do not need any credit at all during the crisis.

Zombie firms: $\bar{a}_{N}>a \geq \bar{a}_{C}$

Firms will be able to survive with the credit during the crisis, but they will not be able to repay the debt in the future. Thus, the guaranteed credit during the crisis leads to an overindebtedness of the firm. This would be commonly referred to as zombie firms, that are kept alive only because of the government intervention. These exist due to the productivity wedge between $\bar{a}_{N}$ and $\bar{a}_{C}$.

Dying firms: $\bar{a}_{N}<\bar{a}_{C}<a$

Note that in this scenario the repayment constraint is stricter than the new normal viability condition, that is, $\bar{a}_{N}>\tilde{a}_{N}$. Thus, in this case all firms with a productivity $\bar{a}_{C}>a>\tilde{a}_{N}$ would be viable in the new normal, but have to default as they are unable to finance their fixed operational costs during the crisis with federal loans. We refer to this firms as 'dying'. For these firms higher federal loans would not ensure their long-term survival, but these loans would turn them into zombies.

Case 2: $\bar{a}_{N}>\tilde{a}_{N}>\bar{a}_{c}$

As in case 1 the repayment constraint is binding, but now $\tilde{a}_{N}>\bar{a}_{C}$, that is, all firms that are in the market have access to sufficient credit. This implies that only good firms and zombie exist in this case. If policy makers intend to freeze the economy, this scenario would represent a situation in which the market structure is persevered during the crisis. However, in the new normal none of the zombie firms would be able to repay its debt. To defrost the economy and keep the current industry structure the government would need to implement a debt-relief for all firms. Alternatively, firms could undertake transformative investments to increase their new normal sales, that is, a higher $\lambda_{N}$.

Case 3: $\bar{a}_{C}>\bar{a}_{c}>\tilde{a}_{N}$ 
In case 3 the debt constraint becomes binding. The guaranteed credit is not sufficient to ensure the survival of the firm during the crisis, although it could repay the credit in the future. ${ }^{13}$ These firms are left behind from the federal loan program and are defaulting during the crisis, although all of them would be viable firms in the new normal.

From a policy maker perspective two facts are important. First, the level of guaranteed debt is crucial. If it is too low, the number of firms left behind to die increases. But on the other hand, a high level of guaranteed credit will create more zombie firms. Thus, it is important to determine in which situation the economy is, that is, are more or less loans needed. Second, all zombie firms could in principle be resurrected by forgiving their debt, as they are all viable firms in the new normal. This is due to the assumption that $\lambda_{B}=\lambda_{N}$. Thus, once the economic situation has improved to previous levels, an expost debt-relief could be a valuable policy instrument. The former situation implies high unemployment rates during the crisis, while the later leads to higher public spending as the government covers the guaranteed loans of defaulting firms. Another solution could be possible, firms could change their business model during the crisis to obtain higher post-crisis sales and thus be able to repay their debt in the new normal. Thus, the federal loans could be used to nudge firms to undertake these transformative investments.

\subsection{Closing the model}

The model follows closely the standard Chaney (2008) model for a closed economy. To derive the equilibrium we need to consider the binding zero profit conditions for each case and period (Table 1).

The equilibrium solution of the model for the pre-crisis and the crisis cutoffs can be derived analogously to the Chaney (2008) model. The same applies to the new normal in case 3, where we assume that there is no immediate new entry in the new normal. In this paper we focus on the behavior of firms during and directly after the crisis and less on the dynamic adjustments of new firms entering after the crisis. ${ }^{14}$ In cases 1 and 2 the cutoff $\bar{a}_{N}$ depends on the past debt level, which is a function of the economic downturn $\lambda_{C}$ and the associated price index. From the perspective of firms in the new normal this will be an exogenous (past) additive component for the cutoff value, that is, the repayment of the federal loans can be seen as additional fixed operational costs. Specifically, for case 1 these additional fixed costs are $M$ for the marginal firm. Appendix A derives the analytical closed form solutions for cases 1 and 3 in more detail.

13 The situation changes slightly if we allow firms to take up higher levels of debt at a positive interest rate (and possibly using collateral assets), that is, $K^{\star}>M$. In this case the federal government is not guaranteeing the whole credit, but a bank will evaluate the credit application and charge some interest. This implies different cutoffs, i.e., the bank will demand a higher new normal productivity $\hat{a}_{N}$ to ensure the repayment. Hence the cutoff for firms will be higher $\hat{a}_{N}>\bar{a}_{N}$. This implies that there will be some firms that could use a higher additional credit to survive the crisis, but would not be able repay the debt in the new normal, although they would be viable firms, $\hat{a}_{N}>\tilde{a}_{N}$. The bank would not allow them to take up sufficient credit and some firms would still be left behind to die. Formally extending the model in this regard will not change the general mechanism and intuition of the model.

14 Note that the cutoff for viable firms in the new normal $\tilde{a}_{N}<\bar{a}_{N}$ and hence new firms should enter. 
Table 1. Binding zero profit cutoffs

\begin{tabular}{lccc}
\hline & Pre-crisis & Crisis & New normal \\
\hline Case 1 & $\tilde{a}_{B}=\tilde{a}_{N}$ & $\bar{a}_{C}$ & $\bar{a}_{N}$ \\
Case 2 & $\tilde{a}_{B}=\tilde{a}_{N}$ & $\tilde{a}_{N}$ & $\bar{a}_{N}$ \\
Case 3 & $\tilde{a}_{B}=\tilde{a}_{N}$ & $\bar{a}_{C}$ & $\bar{a}_{C}$ \\
\hline
\end{tabular}

\subsection{Comparative statics}

Understanding the impact of different variables on the cutoffs within the model is essential. In this section, we discuss the impact of the two policy variables: $\lambda_{C}$ and $M$. By implementing lockdown measures such as social distancing or even banning certain business activities the government indirectly determines the degree of economic downturn $\lambda_{\mathrm{C}}$.

For simplicity we are only considering the first-order (direct) effect and neglecting the (indirect) effects via the price indices.

Economic downturn: $\lambda_{\mathrm{C}}$

$$
\frac{\partial \bar{a}_{C}}{\partial \lambda_{C}}<0
$$

$\lambda_{C}$ does not only impact the debt constraint, but also the repayment constraint in Equation (13).

$$
\frac{\partial \bar{a}_{N}}{\partial \lambda_{C}}<0
$$

A more severe recession, that is, lower $\lambda_{C}$ will increase the repayment cutoff $\bar{a}_{N}$. Intuitively, a bigger decline of the demand for goods during the crisis implies a greater demand for credits, given the firm-level productivity $a$, see Equation (10). Intuitively, if a firm needs to take up high levels of debt during the crisis, repayment becomes harder. Thus, a lower $\lambda_{C}$ implies also a higher $\bar{a}_{N}$, that is, only more productive firms are able to repay their debts in the new normal.

\section{Guaranteed credits: $M$}

Providing higher guaranteed credits to companies will increase the debt cutoff $\bar{a}_{C}$, that is, a greater share of (less productive) firms will be able to cover the fixed costs with a loan. This ultimately might create more zombie firms in the economy.

\subsection{Policy space}

In our model it is crucial to distinguish between all cases. In case 3 a potentially larger share of firms that could repay their debt in the future is left behind to default during the crisis, $\bar{a}_{N}<\bar{a}_{C}$. Considering the negative effects of job losses see Hamermesh (1989) or Pissarides (1992), policy makers might want to avoid this scenario. However, in case 1 zombie firms are created.

The two policy variables $M$ and $\lambda_{C}$ impact the two cutoffs and hence potentially determine in which case the economy is. As long as 


$$
\bar{a}_{C}>\bar{a}_{N}
$$

the economy is in case 3, where some firms will not be able to obtain sufficient credit to survey the crisis, although they could repay their debt in the future. Substituting the cutoffs from Equations (7) and (13) yields the condition for the economy to be in a case 3 scenario:

$$
(2 f)^{\frac{1}{\epsilon-1}}\left(\frac{\lambda_{N}}{P_{N}^{1-\epsilon}}+\frac{\lambda_{C}}{P_{C}^{1-\epsilon}}\right)^{\frac{1}{1-\epsilon}} \leq(f-M)^{\frac{1}{\epsilon-1}}\left(\frac{\lambda_{C}}{P_{C}^{1-\epsilon}}\right)^{\frac{1}{1-\epsilon}}
$$

Given that the elasticity of substitution is greater than unity, we simplify the expression to obtain

$$
\lambda_{C} \leq \lambda_{N}\left(\frac{P_{C}}{P_{N}}\right)^{1-\epsilon} \frac{f-M}{f+M}
$$

Everything else equal, a higher level of guaranteed federal loans pushes the economy towards case 1 and hence potentially creates zombie firms. However, a stronger economic downturn, that is, lower $\lambda_{C}$, moves the economy in the direction of case 3 . One might argue that a case 3 scenario should be avoided, as (some of) the firms left behind to die during the crisis would be viable and able to repay their debt in the future, which would suggest a higher $M$. However, if $M$ is too high it will result in a situation in which $\bar{a}_{C}<\bar{a}_{N}$. In this case zombie will be created.

If $\bar{a}_{N}=\bar{a}_{C}$, all firms that take up loans during the crisis are able to repay the debt and no zombie firms will be created. Still, in this situation some firms are left behind to die, although they would be viable firms in the new normal:

$$
\tilde{a}_{N} \leq \bar{a}_{C} .
$$

Substituting Equation (8) for $j=N$ and Equation (7) yields the following inequality

$$
f^{\frac{1}{\epsilon-1}}\left(\frac{\lambda_{N}}{P_{N}^{1-\epsilon}}\right)^{\frac{1}{1-\epsilon}} \leq(f-M)^{\frac{1}{\epsilon-1}}\left(\frac{\lambda_{C}}{P_{C}^{1-\epsilon}}\right)^{\frac{1}{1-\epsilon}} .
$$

After simplifying we obtain

$$
\lambda_{C} \leq \lambda_{N}\left(\frac{P_{C}}{P_{N}}\right)^{1-\epsilon} \frac{f-M}{f} .
$$

These two inequalities determine the policy space for guaranteed federal loans. If the maximum amount of loans relative to the economic downturn (caused by lockdown measures) $\lambda_{C}$ is too low, this will create firms left behind to die. If the maximum amount of loans is too high relative to the economic downturn, zombie firms are created. Figure 3 plots the two Equations (14) and (17). Both are convex and the relationship described by Equation (14) is always weakly below the condition described by Equation (17). While the two conditions coincide at the intercepts of the $x$ - and $y$-axis they diverge for intermediate 


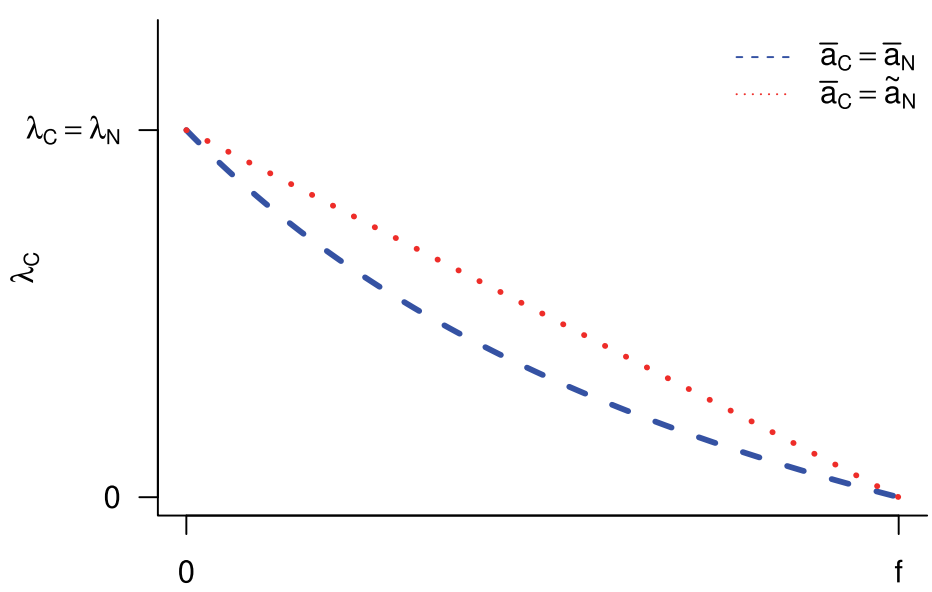

M

Figure 3. Relationship between the degree of lockdown, $\lambda_{c}$, and the maximum amount of loans to firms, $M$. Combinations of $M$ and $\lambda_{C}$ below the dashed line imply a case 2 scenario. Combinations of $M$ and $\lambda_{C}$ above the dotted line imply the creation of maximum number of zombie firms. All combination of $\mathrm{f} M$ and $\lambda_{C}$ in the area between the curves indicate the co-existence of zombie firms and firms with insufficient access to loans and hence leaving the market during the crisis.

values of $M$ and $\lambda_{C}$. In terms of our model all $\lambda_{C}$ and $M$ combinations to the left of the dashed line depict a case 3 scenario. All $\lambda_{C}$ and $M$ combinations to the right of the dotted line represent case 2 scenarios and all points between the two lines are case 1 scenarios.

This implies a trade-off between leaving firms behind (not preserving the industry structure before the crisis) and creating zombie firms. If policy makers want to avoid the creation of zombie firms and hence minimize its costs due to (zombie) firms defaulting on the guaranteed loans, they have to choose a $\lambda_{C}$ and $M$ combinations on the dashed line. If policy makers want to preserve the industry structure and include all firms that would be viable in the new normal, they have to choose $\lambda_{C}$ and $M$ combinations on the dotted line. Note that the possible policy space gets smaller for more extreme values of $\lambda_{C}$ and $M$.

\subsection{Model predictions}

The stylized model of financially constraint firms in a COVID-19 induced economic downturn gives some insightful predictions of firm behavior. First, in a scenario of case 1 or 2 for any given level of demand higher productivity firms will be more profitable before the crisis and more likely to be of the 'good' type, that is, able to obtain sufficient credit and to repay it. In the same scenarios low productivity firms, that is, firms facing low demand already before the crisis, will not be able or willing to take up federal loans. Second, the recession curve matters. The more severe the downtown, the less firms will be of the 'good' type. Similarly, a better expected new normal situation facilitates the repayment of the debt and hence increases the share of good firms and decreases the share of zombies. We can think of the past business situation as the best predictor of the new normal situation, that is, 
$E\left(\lambda_{N}\right)=\lambda_{B}$. Thus, a better initial business situation of firms will increase the take up of debt, while a worse current situation decreases it.

\section{Empirical Analysis}

In this section, we provide some empirical evidence that are consistent with our stylized theoretical model.

\subsection{Data}

We conducted an exploratory, online survey among managers of Swiss firms. Most of the respondents were recruited using the MBA alumni network of the ZHAW (about 80\%) using direct email. Moreover, social media channels were used, where we cooperated with Swiss trade associations and relied on the word of mouth. The survey was only open for 1 week, from 7 to 13 April 2020. Almost $90 \%$ of the respondents answered the survey on the first 3 days. In total we surveyed 205 managers of Swiss companies about their perception and expectation of the past, current and future business situation of their companies. We also asked a rich set of complementary questions about their firm's reaction towards the COVID-19 crisis.

As any opt-in online survey there is self-selection into the survey, which might lead to biased results. In a common treatment setup, where we could simultaneously observe treated and untreated units a standard Heckman (1979) correction would be used to deal with self-selection. In surveys this is not possible, see Lavrakas (2008). Bethlehem (2010) suggests several methods to deal with possible selection bias in a convenience sample such as ours. The most common approach would be a post-stratification, where weights are assigned to each observation within a clearly defined stratum to ensure representativeness. Alternatively D'Orazio et al. (2006) suggest a matching procedure to deal with selfselection into surveys. Observations from a representative target sample are matched with the most similar observations from the opt-in survey. Once all target observations are matched, all the remaining unmatched observations from the opt-in survey are discarded. This procedure prevents over-sampling due to self-selection.

Relying on opt-in survey data has clear empirical limitations and thus all results should be interpreted with caution keeping a possible self-selection bias in mind. ${ }^{15}$

The collected data cover a wide range of sectors and firms of different sizes, see Figures 4-6. We show a more detailed data regarding the representativeness of our sample in the Appendix C, where we compare the distribution of our sample to the distribution of the universe of Swiss firms (about 550,000 firms in 2018). In terms of the sectoral composition our sample is fairly representative. The greatest differences are in the share of firms in the manufacturing sector (18 percentage points oversampling) and the health care sector (11 percentage points undersampling), see Table C1 in the Appendix C. As it is common for opt-in online surveys we oversample bigger firms, that is, while firms with

15 A certain self-selection of firms based on their business situation before and during the crisis is likely. Yet, we believe that this self-selection is less based on loan take-ups, which would introduce a severe bias to our results. Indeed, the invitation to the survey did not mention federal loans at all and we observe no change in the dropout rates before and after the questions regarding federal loan take-up in the survey. 


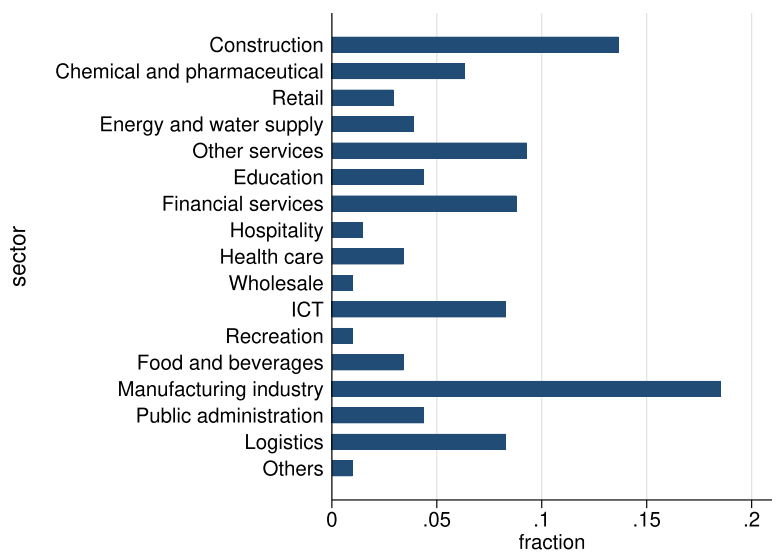

Figure 4. Distribution of firms by sector. Aggregated Swiss NOGAS classification.

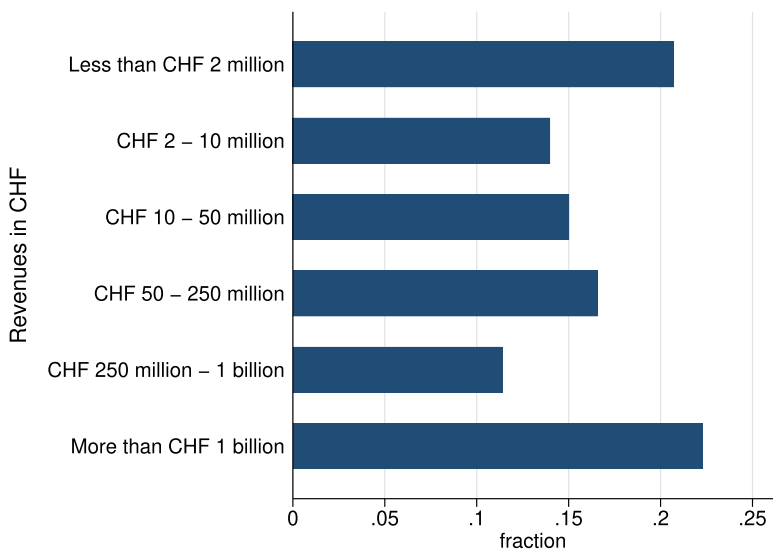

Figure 5. Distribution of firms by level of revenues in CHF.

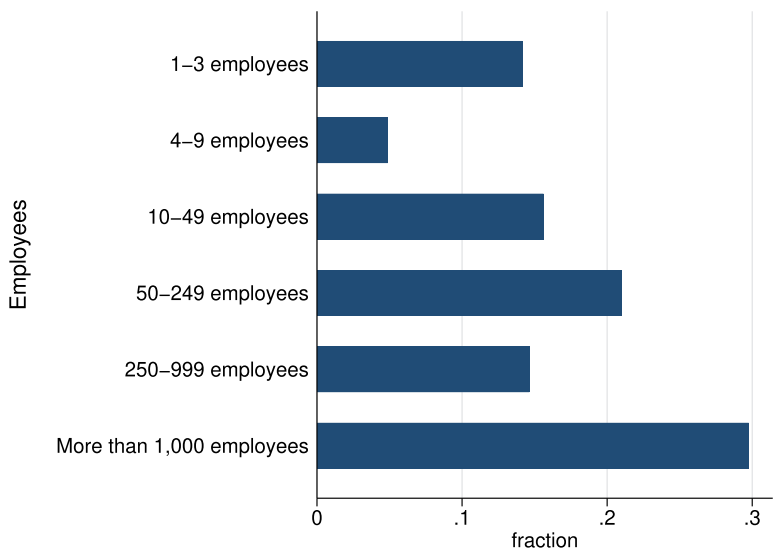

Figure 6. Distribution of firms by number of employees. 
more than 250 employees represent only $0.35 \%$ of Swiss firms in our sample their share is $44.39 \%$, see Table C2 in the Appendix C. The greater number of employees in bigger firms increases the probability of surveying this firm. This also contributes to the deviations we observe in terms of the sectoral distribution. Firms are in general much bigger in the manufacturing sector than in the health care sector, where for example family doctors office with very few employees is very prevalent. In terms of the geographical distribution over $60 \%$ of the firms are located in the canton of Zurich, which represents the economic center of Switzerland. ${ }^{16}$ Other regions are under-represented, for example Ticino, which due to its geographical proximity to Italy was initially one of the cantons with the highest infection rates, but only represents around $1.23 \%$ of our sample. ${ }^{17}$

In general the survey reflects more the representative employee and the respective employer than the representative firm. In this regard we consider the survey fairly representative for the Swiss economy, although the geographical focus is clearly on the German speaking regions of Switzerland.

The detailed descriptive statistics are provided in Table B1 in the Appendix B. The complete survey questionnaire is available in the Supplementary Appendix.

\subsection{Analysis}

Managers were asked to assess their past business situation (in 2019), their current business situation (7-13 April 2020) and the business situation they expect at the peak economic impact of the COVID-19 crisis. While the median firm in our survey assessed its business situation in 2019 as good, this deteriorated significantly over time, see Figure 7. More importantly, while in 2019 no firm perceived its business situation as threatening the firm's survival (existential threat), this increased to $7 \%$ of firms at the point of the survey and more than $12 \%$ of firms expected to fight for their survival at the peak economic impact of the COVID-19 crisis.

Firms that had a more favorable business situation in 2019 had significant higher revenues (coefficient of 0.1617 and $p$-value of 0.094 ) after controlling for size (employees), sector fixed effects, and firm type multinational enterprises (MNE). This relationship becomes insignificant for the assessment of the current business situation, while the expected business situation at the peak economic impact is positively impacted by the employment levels (coefficient 0.3886 and $p$-value 0.091 ).

Table 2 shows the unconditional correlation between the three answers regarding the perceived business situation in 2019, at the moment of the survey and the expected business situation at the peak economic impact of the COVID-19 crisis. Firms that had a more positive perception of their business situation expected a smaller impact of the crisis. Even when controlling for industry and fixed effects this positive relationship persists: coefficient 0.525 and standard error 0.138 . Thus, the COVID-19 crisis seems to have a more severe impact on firms that were already under-performing before the crisis. ${ }^{18}$

17 Only about $4 \%$ of the Swiss population lives in Ticino.

18 In terms of our model we could interpret the perceived business situation as a combination of the demand shift $\lambda_{j}$ and the firm-specific productivity, a. Specifically, we could use a multiplicative function $a \lambda_{j}$, which would be consistent with these correlations. 


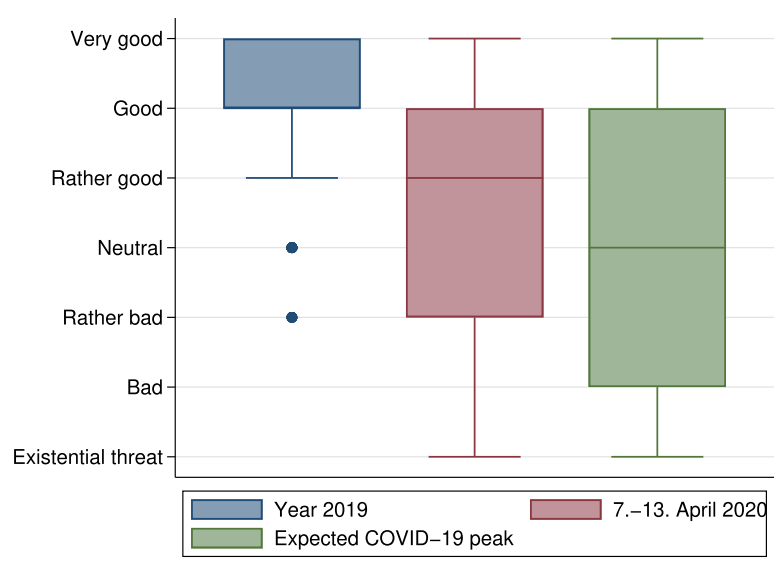

Figure 7. Whisker plot: Business situation in 2019, at the current point in time and expectation during the COVID-19 crisis. Ratings on a scale of -3 (existential threat) to +3 (very good).

Table 2. Correlation matrix business situation

\begin{tabular}{lcccr}
\hline & & \multicolumn{3}{c}{ Business situation } \\
\cline { 3 - 5 } & & 2019 & April 2020 & Peak \\
\hline Business situation & 2019 & 1.000 & & \\
& April 2020 & 0.241 & 1.000 & \\
Peak & 0.257 & 0.868 & 1.000
\end{tabular}

Note: Correlation matrix of the business situation in 2019, during the survey (April 2020), and expected business situation at the peak economic impact of the COVID-19 crisis.

Next we estimate the impact of various factors on the current and expected business environment of the firms in our survey. Specifically, we estimate the following two specifications

$$
y_{i t}=k_{1}+X_{i} \beta_{1}+Z_{i} \eta_{2}+\nu_{s}+\phi_{m}+\tau_{u}+\epsilon_{i t},
$$

and

$$
y_{i t+1}=k_{2}+X_{i} \beta_{2}+Z_{i} \eta_{2}+\nu_{s}+\phi_{m}+\tau_{u}+\epsilon_{i t+1},
$$

where $y_{i t}$ and $y_{i t+1}$ is the surveyed manager's evaluation of his firms current and future business situation, respectively. $k$ is a constant, $X_{i}$ are firm-level controls such as number of employees and total revenues. $Z_{i}$ is a vector of business' assessment of COVID-19 related problems and firm-level responses. $\nu_{s}$ are sector fixed effects. $\phi_{m}$ are fixed effects regarding the MNE status of the firm, that is, purely domestic firm, foreign owned MNE, and Swiss owned MNE. Last, $\tau_{u}$ are survey time fixed effects for the 7, 8, 9, and 10-13 April 2020. ${ }^{19}$

19 Ninety percent of the respondents answered the survey in the first 3 days, so we included separate fixed effects for each of these days in the regression. The 10-13 April 2020 were bank holidays in Switzerland (Eastern) and thus very little information about changes of the COVID-19 pandemic were published during these days. In addition, the low number of respondents during 
$\epsilon_{i t}$ and $\epsilon_{i t+1}$ are error terms. With our fixed effect specification we use the variation of firms within the same sector, while controlling for the type of firm (domestic, Swiss owned MNE or foreign owned MNE) and the actual time of the survey response. The two fixed effects ensure that firms are similar (same sector and type) which allows for a better identification of COVID-19 effects at the firm level.

Table 3 shows the estimation of the determinants of the current and expected business situations for the firms in our survey. Note that the perceived and expected business situations are strongly impacted by the foreign demand, that is, a higher foreign demand improves the business situation. It appears that firms in a small and very open economy such as Switzerland depend to a great extend on the foreign demand. However, neither domestic nor foreign supply of production inputs seems to be a mayor issue for the firms in the survey.

There is some weak evidence that firms that prepared more for possible COVID-19 disruptions-before the first Swiss COVID-19 case was detected-were doing better during the crisis. ${ }^{20}$ In terms of specific reactions only offering home office has a positive impact on the perceived current business situation, but this effect becomes insignificant at the peak economic impact of the COVID-19 crisis. In general we have to be careful to interpret this regression table as many variable are likely to be biased due to endogeneity, that is, reducing the business activity of course dramatically changes the perceived and expected business situations, but also might be the result of the worse business situation, that is, reverse causality. Indeed several of the factors identified by Goodman-Bacon and Marcus (2020) make the use of techniques such as difference-in-difference estimations to establish a causal relationship less feasible for Switzerland. Besides the reverse causality, spillovers effects (stable treatment unit) might be a significant factor in Switzerland, that boarders four countries, among them (Northern) Italy that has been a COVID-19 hot spot. Thus, isolating the impact of certain Swiss policies on Swiss firms might be difficult. In addition, some Swiss regional policy measures might have been timed differently and hence been staggered leading to biased estimates. Given these limitations showing clear correlations that might or not be causal can be already an important reference point for policy makers.

To account for some of the aforementioned effects we amend the estimate Equations (18) and (19) by including region (canton) fixed effects. The canton fixed effects subsume all regional-specific effects such as regional policy measures and thus providing a clearer view on the average effect. ${ }^{21}$ The results of this robustness check are presented in Table D1 in the Appendix D. The estimations are qualitatively similar, but the data set is much smaller due to missing firm location information.

To construct a recession curve based on firm-level answers we asked the managers when they are expecting the peak economic impact of the COVID-19 crisis and when their company expects to return to a normal business environment. Figures 8 and 9 show the distribution of answers.

these days makes statistical interference very imprecise. We use only on fixed effects that covers all three days. All results are robust to the exclusion of survey answers between 10 April and 13 April 2020.

20 China reported the first COVID-19 cases to the WHO on 1 January 2020 and Switzerland reported the first cases at the end of February 2020.

21 No regional or federal COVID-19 measures were introduced or came into force during the survey. 
Table 3. Estimation: business situation

\begin{tabular}{|c|c|c|c|c|c|c|}
\hline & \multicolumn{3}{|c|}{ April 2020} & \multicolumn{3}{|c|}{ Expected peak COVID } \\
\hline & $\begin{array}{l}\text { Problems } \\
\text { (1) }\end{array}$ & $\begin{array}{l}\text { Reaction } \\
\text { (2) }\end{array}$ & $\begin{array}{l}\text { All } \\
(3)\end{array}$ & $\begin{array}{c}\text { Problems } \\
\text { (4) }\end{array}$ & $\begin{array}{c}\text { Reaction } \\
(5)\end{array}$ & $\begin{array}{l}\text { All } \\
(6)\end{array}$ \\
\hline Employees & $\begin{array}{r}-0.011 \\
(0.317)\end{array}$ & $\begin{array}{l}0.377^{* * *} \\
(0.189)\end{array}$ & $\begin{array}{c}0.086 \\
(0.312)\end{array}$ & $\begin{array}{c}0.190 \\
(0.338)\end{array}$ & $\begin{array}{c}0.402^{*} \\
(0.212)\end{array}$ & $\begin{array}{c}0.208 \\
(0.344)\end{array}$ \\
\hline Revenues & $\begin{array}{c}0.179 \\
(0.324)\end{array}$ & $\begin{array}{r}-0.226 \\
(0.190)\end{array}$ & $\begin{array}{r}-0.034 \\
(0.303)\end{array}$ & $\begin{array}{c}-0.032 \\
(0.342)\end{array}$ & $\begin{array}{r}-0.143 \\
(0.213)\end{array}$ & $\begin{array}{r}-0.080 \\
(0.332)\end{array}$ \\
\hline Ban business activities & $\begin{array}{c}0.180 \\
(0.163)\end{array}$ & & $\begin{array}{r}-0.012 \\
(0.165)\end{array}$ & $\begin{array}{c}0.183 \\
(0.175)\end{array}$ & & $\begin{array}{c}0.026 \\
(0.183)\end{array}$ \\
\hline Domestic demand & $\begin{array}{c}0.265 \\
(0.168)\end{array}$ & & $\begin{array}{c}0.185 \\
(0.158)\end{array}$ & $\begin{array}{c}0.179 \\
(0.176)\end{array}$ & & $\begin{array}{c}0.085 \\
(0.171)\end{array}$ \\
\hline Foreign demand & $\begin{array}{l}0.435^{* \ldots *} \\
(0.206)\end{array}$ & & $\begin{array}{c}0.370^{*} \\
(0.200)\end{array}$ & $\begin{array}{l}0.482^{* * *} \\
(0.217)\end{array}$ & & $\begin{array}{c}0.430^{*} \\
(0.219)\end{array}$ \\
\hline Domestic supply & $\begin{array}{r}-0.079 \\
(0.194)\end{array}$ & & $\begin{array}{r}-0.137 \\
(0.188)\end{array}$ & $\begin{array}{c}0.007 \\
(0.202)\end{array}$ & & $\begin{array}{c}0.064 \\
(0.204)\end{array}$ \\
\hline Foreign supply & $\begin{array}{r}-0.004 \\
(0.210)\end{array}$ & & $\begin{array}{r}-0.094 \\
(0.197)\end{array}$ & $\begin{array}{r}-0.137 \\
(0.220)\end{array}$ & & $\begin{array}{r}-0.275 \\
(0.213)\end{array}$ \\
\hline Workers at home & $\begin{array}{r}-0.003 \\
(0.164)\end{array}$ & & $\begin{array}{r}-0.023 \\
(0.163)\end{array}$ & $\begin{array}{r}-0.102 \\
(0.171)\end{array}$ & & $\begin{array}{r}-0.148 \\
(0.176)\end{array}$ \\
\hline Finance & $\begin{array}{c}0.075 \\
(0.147)\end{array}$ & & $\begin{array}{c}0.086 \\
(0.145)\end{array}$ & $\begin{array}{c}0.139 \\
(0.157)\end{array}$ & & $\begin{array}{c}0.081 \\
(0.161)\end{array}$ \\
\hline Preparation & & $\begin{array}{c}0.164^{*} \\
(0.088)\end{array}$ & $\begin{array}{c}0.023 \\
(0.131)\end{array}$ & & $\begin{array}{c}0.178^{*} \\
(0.098)\end{array}$ & $\begin{array}{r}-0.017 \\
(0.142)\end{array}$ \\
\hline Stop business & & $\begin{array}{c}-1.097^{* * *} \\
(0.443)\end{array}$ & $\begin{array}{c}-1.424^{* *} \\
(0.608)\end{array}$ & & $\begin{array}{c}-0.997^{* * *} \\
(0.495)\end{array}$ & $\begin{array}{r}-0.905 \\
(0.659)\end{array}$ \\
\hline Cost reduction & & $\begin{array}{c}-1.273^{* * *} \\
(0.302)\end{array}$ & $\begin{array}{c}-1.166^{* *} \\
(0.453)\end{array}$ & & $\begin{array}{c}-1.062^{* \ldots *} \\
(0.337)\end{array}$ & $\begin{array}{c}-1.327^{* \ldots *} \\
(0.493)\end{array}$ \\
\hline Reduce business & & $\begin{array}{r}-0.223 \\
(0.297)\end{array}$ & $\begin{array}{r}-0.328 \\
(0.425)\end{array}$ & & $\begin{array}{c}0.016 \\
(0.333)\end{array}$ & $\begin{array}{r}-0.241 \\
(0.464)\end{array}$ \\
\hline Bundeshilfe & & $\begin{array}{c}-1.197^{* * *} \\
(0.541)\end{array}$ & $\begin{array}{r}-0.974 \\
(0.833)\end{array}$ & & $\begin{array}{c}-1.479^{* *} \\
(0.604)\end{array}$ & $\begin{array}{r}-1.219 \\
(0.900)\end{array}$ \\
\hline Home Office & & $\begin{array}{l}1.096^{* * *} \\
(0.426)\end{array}$ & $\begin{array}{l}1.375^{* *} \\
(0.653)\end{array}$ & & $\begin{array}{c}0.428 \\
(0.477)\end{array}$ & $\begin{array}{c}0.734 \\
(0.707)\end{array}$ \\
\hline Change of Business Model & & $\begin{array}{r}-0.260 \\
(0.747)\end{array}$ & $\begin{array}{c}-0.409 \\
(1.250)\end{array}$ & & $\begin{array}{r}-0.316 \\
(0.834)\end{array}$ & $\begin{array}{r}-1.115 \\
(1.355)\end{array}$ \\
\hline New products/services & & $\begin{array}{r}-0.586 \\
(0.415)\end{array}$ & $\begin{array}{r}-0.967 \\
(0.673)\end{array}$ & & $\begin{array}{r}-0.418 \\
(0.463)\end{array}$ & $\begin{array}{r}-0.653 \\
(0.728)\end{array}$ \\
\hline Digitalization & & $\begin{array}{r}-0.068 \\
(0.344)\end{array}$ & $\begin{array}{c}0.250 \\
(0.475)\end{array}$ & & $\begin{array}{r}-0.134 \\
(0.384)\end{array}$ & $\begin{array}{c}0.689 \\
(0.516)\end{array}$ \\
\hline Delivery & & $\begin{array}{r}-0.997 \\
(1.426)\end{array}$ & $\begin{array}{r}-0.322 \\
(1.759)\end{array}$ & & $\begin{array}{r}-0.935 \\
(1.592)\end{array}$ & $\begin{array}{c}0.070 \\
(1.903)\end{array}$ \\
\hline Obs. & 104 & 163 & 101 & 104 & 162 & 100 \\
\hline Adj. $R^{2}$ & 0.221 & 0.361 & 0.37 & 0.162 & 0.265 & 0.274 \\
\hline
\end{tabular}

Notes: Fixed effect estimation of the current and expected business situation. Sector fixed effects, survey time fixed effects, and MNE fixed effects. Robust standard errors clustered at the sector level in parentheses. ***, $* *$, and $*$ denote statistical significance at the $1 \%, 5 \%$, and $10 \%$ level, respectively. 


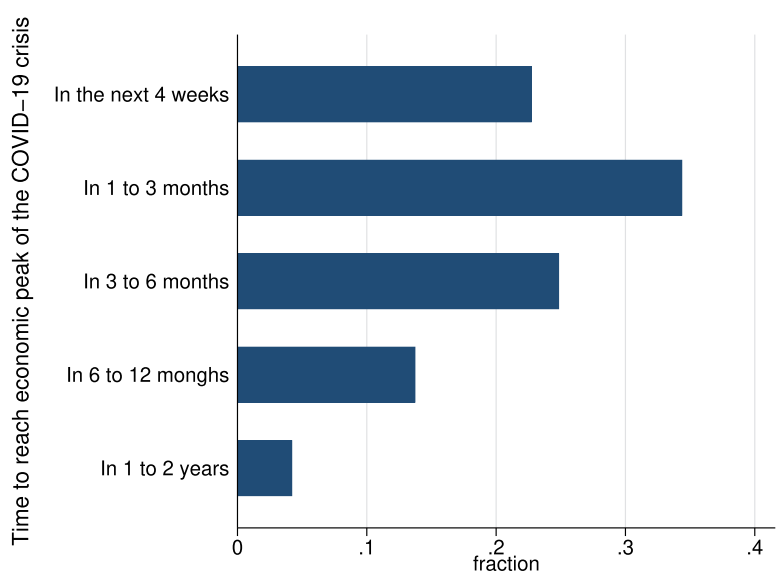

Figure 8. Time a firm expects to reach the peak economic impact starting from the week 7-13 April 2020.

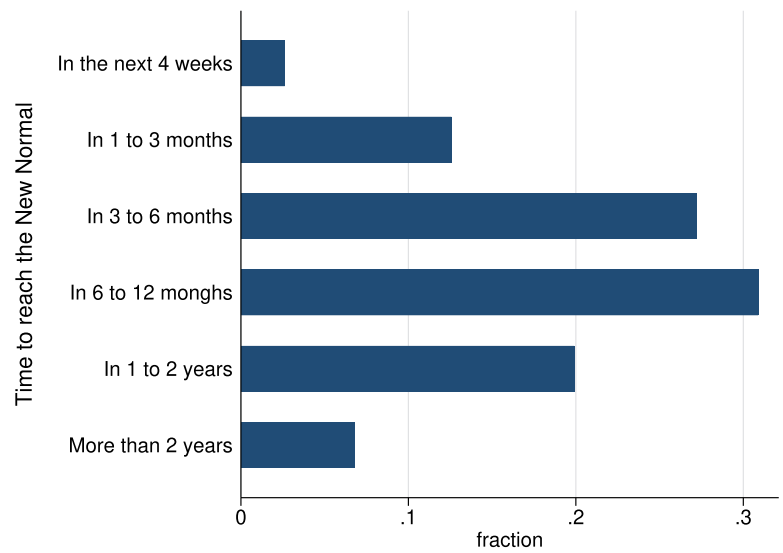

Figure 9. Time a firm expects to reach the new normal starting from the week 7-13 April 2020.

As the answer options for the survey participants were ordinal with a varying range and a right-censoring (more than 2 years) we follow Wooldridge (2013) and estimate the mean and standard deviation of the distribution and account for the varying censoring limits by using a generalized tobit model. This allows us to compute the unconditional mean and the standard deviation in the presence of right-censoring. The peak economic impact of the crisis is expected after 14.4 weeks (standard error 0.99) and the new normal is reached after 39.6 weeks (standard error 2.28). Figure 10 shows the stylized recession curve akin to Baldwin (2020) and Gourinchas (2020). The managers in our survey expected the peak economic impact in July 2020, indicating that firms were still in crisis mode during the survey.

In general firms could try to react more pro-actively to the COVID-19 crisis, for example, they could move to more digital business models. In our survey the most favored reactions are trying to mitigate the impact of the crisis, that is, home office followed by short-time work. Only a few firms pro-actively engaged the crisis situation and tried to gain 


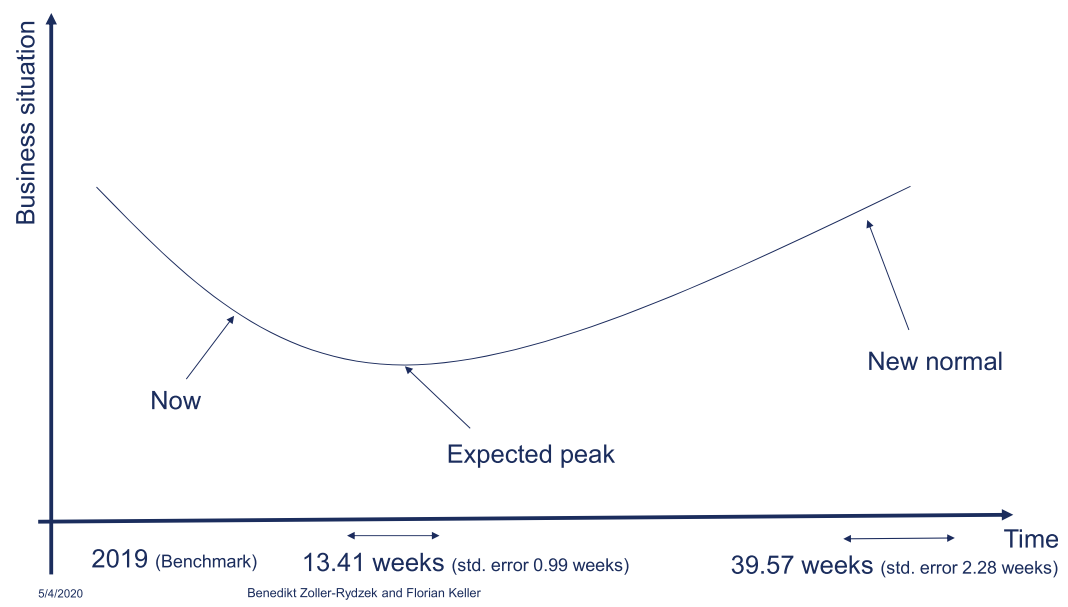

Figure 10. Firm-level recession curve. Weeks to peak economic impact and the new normal. Based on the 7-13 April 2020 survey.

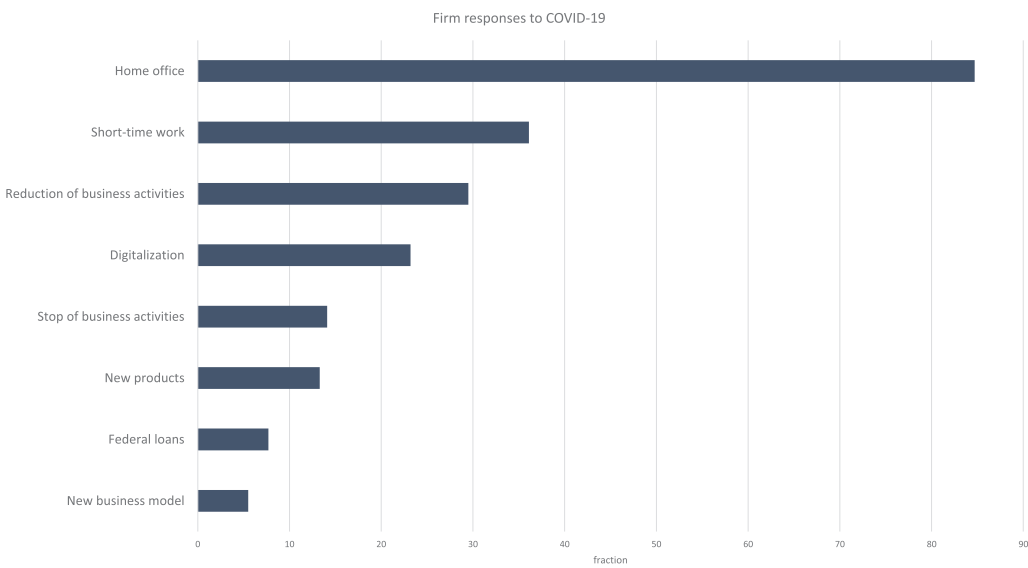

Figure 11. Share of firms using ness. Multiple responses were allowed. as a response to mitigate the impact of COVID-19 on their busi-

market shares by changing their business model or introducing new products. Figure 11 shows the fraction of firms in the survey using different actions to deal with the crisis. This indicates that the economic activity of most firms was actually frozen and no mayor transition of activities occurred during the lockdown period before the survey took place.

This shows that most firms perceive the COVID-19 crisis as transitory, that is, once lockdown measures would be lifted their business situation would return to normal levels. This is consistent with our assumption regarding the identical pre- and post-crisis business situations, $\lambda_{B}=\lambda_{N}$. However, from a policy perspective a radical change of business models could improve the new normal business situation for firms and hence enable more firms to repay their debt. 
Last, we are investigating the take up of the Swiss federal guaranteed loan program. The theoretical model in Section 4 predicted that firms with a better business situation are more likely to take up loans during the crisis, while firms in a worse business situation would be over-indebted with the federal loans and hence would not take up any debt. We estimate the following specification

$$
b_{i}=k_{3}+X_{i} \beta_{3}+Z_{i} \eta_{3}+\sigma y_{i t}+\nu_{s}+\phi_{m}+\tau_{u}+\epsilon_{i},
$$

where $b_{i}$ is an indicator variable if the firm $i$ has taken up federal loans, $y_{i t}$ is the assessment of the business situation in 2019, April 2020, and the expected situation during the peak economic impact of COVID-19 crisis. We also include first difference of the business situation in the estimation to consider more dynamic affects. We use the same specification as in Equation (20) to estimate the take up of the Swiss short-time work program.

Table 4 shows the estimation results of a linear probability model for the take up of federal loans. Clearly the business situation in 2019 has a positive impact on the probability to take up federal loans. Also a more severe drop in the business situation between 2019 and the time of the survey leads to a higher take up probability, see column (4) in Table 4. These results are only consistent with case 1 and case 3 scenarios, as in case 2 all firms in the market would take up credits.

Table 4. Estimation: federal loan take up

\begin{tabular}{|c|c|c|c|c|}
\hline & $(1)$ & (2) & (3) & (4) \\
\hline \multirow[t]{2}{*}{ Employees } & 0.027 & 0.043 & 0.049 & 0.048 \\
\hline & $(0.031)$ & $(0.039)$ & $(0.039)$ & $(0.039)$ \\
\hline \multirow[t]{2}{*}{ Revenues } & $-0.052^{*}$ & -0.062 & -0.062 & -0.060 \\
\hline & $(0.030)$ & $(0.039)$ & $(0.039)$ & $(0.038)$ \\
\hline \multirow[t]{2}{*}{ Domestic demand } & & -0.030 & -0.013 & -0.013 \\
\hline & & $(0.021)$ & $(0.022)$ & $(0.022)$ \\
\hline \multirow[t]{2}{*}{ Foreign demand } & & -0.016 & 0.001 & 0.005 \\
\hline & & $(0.025)$ & $(0.026)$ & $(0.025)$ \\
\hline \multirow[t]{2}{*}{ Business situation 2019} & $0.040^{*}$ & 0.036 & $0.052^{* * n}$ & \\
\hline & $(0.021)$ & $(0.026)$ & $(0.026)$ & \\
\hline \multirow[t]{2}{*}{ Business situation April 2020} & & & -0.014 & \\
\hline & & & $(0.029)$ & \\
\hline \multirow[t]{2}{*}{ Business situation peak } & & & -0.024 & \\
\hline & & & $(0.026)$ & \\
\hline \multirow[t]{2}{*}{ Diff. 2019 and April 2020} & & & & $0.041 * * *$ \\
\hline & & & & $(0.015)$ \\
\hline \multirow[t]{2}{*}{ Diff. April 2020 and peak } & & & & 0.024 \\
\hline & & & & $(0.026)$ \\
\hline Obs. & 169 & 132 & 130 & 130 \\
\hline Adj. $R^{2}$ & 0.236 & 0.158 & 0.202 & 0.2 \\
\hline
\end{tabular}

Notes: Linear probability model. Sector fixed effects, survey time fixed effects, and MNE fixed effects. Robust standard errors clustered at the sector level in parenthesis. $* * * * *$, and $*$ denote statistical significance at the $1 \%, 5 \%$, and $10 \%$ level, respectively. 
Table 5. Estimation: short-time work take up

\begin{tabular}{|c|c|c|c|c|}
\hline & (1) & $(2)$ & (3) & (4) \\
\hline Employees & $\begin{array}{c}0.021 \\
(0.055)\end{array}$ & $\begin{array}{c}0.068 \\
(0.068)\end{array}$ & $\begin{array}{c}0.078 \\
(0.066)\end{array}$ & $\begin{array}{c}0.084 \\
(0.067)\end{array}$ \\
\hline Revenues & $\begin{array}{c}0.015 \\
(0.054)\end{array}$ & $\begin{array}{l}-0.034 \\
(0.067)\end{array}$ & $\begin{array}{l}-0.031 \\
(0.066)\end{array}$ & $\begin{array}{l}-0.045 \\
(0.067)\end{array}$ \\
\hline Domestic demand & & $\begin{array}{l}-0.052 \\
(0.037)\end{array}$ & $\begin{array}{l}-0.018 \\
(0.037)\end{array}$ & $\begin{array}{l}-0.021 \\
(0.038)\end{array}$ \\
\hline Foreign demand & & $\begin{array}{c}-0.101^{* *} \\
(0.044)\end{array}$ & $\begin{array}{l}-0.066 \\
(0.045)\end{array}$ & $\begin{array}{c}-0.091^{* *} \\
(0.044)\end{array}$ \\
\hline Business situation 2019 & $\begin{array}{l}-0.038 \\
(0.038)\end{array}$ & $\begin{array}{l}-0.049 \\
(0.045)\end{array}$ & $\begin{array}{l}-0.019 \\
(0.045)\end{array}$ & \\
\hline Business situation April 2020 & & & $\begin{array}{l}-0.077 \\
(0.049)\end{array}$ & \\
\hline Business situation peak & & & $\begin{array}{l}-0.001 \\
(0.045)\end{array}$ & \\
\hline Diff. 2019 and April 2020 & & & & $\begin{array}{l}0.057^{* *} \\
(0.026)\end{array}$ \\
\hline Diff. April 2020 and peak & & & & $\begin{array}{l}-0.002 \\
(0.045)\end{array}$ \\
\hline Obs. & 169 & 132 & 130 & 130 \\
\hline Adj. $R^{2}$ & 0.24 & 0.326 & 0.38 & 0.354 \\
\hline
\end{tabular}

Notes: Linear probability model. Sector fixed effects, survey time fixed effects, and MNE fixed effects. Robust standard errors clustered at the sector level in parenthesis. $* * * *$, and $*$ denote statistical significance at the $1 \%, 5 \%$, and $10 \%$ level, respectively.

We include canton fixed effects as a robustness check in Table D2 in the Appendix D. Although the number of observations is considerably lower we still find a significant effect on the change of the business situation, that is, a more severe drop of the business situation leads to a higher probability to take up federal loans. In addition, we estimate the specification in Equation (20) as a probit and logit models. The results are robust and given in the Appendix E in Tables E1 and E2.

Table 5 provides the estimation results of a linear probability model with an indicator for short-time work in the firm as dependent variable. In contrast to Table 4 the business situation in 2019 does not have any impact on the use of short-time work in the firm, see columns (1)-(3). As short-time work is financed through the unemployment insurance of the workers, no (long-term) financial risk arises for the firms. This favors the usage of short-time work by all firms independent of their past business situation. Yet in column (4) we observe a significant positive impact of the change of business situation on short-time work indicating that it is likely to be used to reduce business activities. In terms of our model we could interpret short-time work as a way to reduce fixed costs of production, $f$.

In the Appendix D, we present the linear probability model for short-time work take up including canton fixed effects in Table D2. We also provide robust estimation results of probit and logit models in Tables E3 and E4 in the Appendix E. We also investigate possible heterogeneous effects in terms of firm size (firms with more or less than 50 employees) and firms operating in the service sector vs. firms in the industrial sector. We provide the 
regression results in Tables F1 and F2 in the Appendix F. We find that effects are not very heterogeneous between smaller and bigger firms. In general it appears that most of the observable effects are driven by firms in the service sectors.

\section{Conclusion}

In this paper, we developed a stylized model of financially constraint firms during the COVID-19 crisis. Firms are able to take up debt guaranteed by the (Swiss federal) government to pay for fixed costs during the crisis. We find that three scenarios are possible. First, the amount of guaranteed loans is too low to cover all firms that would be viable or even able to repay the debt after the crisis. This would lead to many firms leaving the market and potentially high unemployment rates during the crisis. Second, the guaranteed loans are more than sufficient for all firms to cover their fixed operational costs, but not all firms will be able to pay back their debt after the crisis. In this case the loans will create a large amount of zombie firms in the economy that would default after the crisis due to their high levels of debt. These zombie firms could be resurrected with an ex-post debt relief. Nevertheless, firms defaulting or providing a government paid debt-relief imply a considerable (additional) spending of public resources. Note that zombie firms defaulting in the new normal are likely to create higher unemployment rates in the future. In this sense any policy that fosters the creation of zombie firms will flatten the unemployment curve, that is, lower current unemployment rates, but higher ones later. Last, an intermediate situation could be possible, that is, loans are sufficient for some (post-crisis viable) firms, but not for all. In this case we would expect some firms to leave the market as credits are not sufficient for them, while other firms become zombies. It turns out that policy makers face a trade-off between providing large amount of loans and the degree to which a lockdown is worsening the business situation.

In general even a loan with a zero interest rate creates a repayment wedge and can lead to over-indebtedness of firms. Two possible solutions arise to this problem. First, the government could use an ex-post debt-relief to avoid zombie firms defaulting. Second, loans could be conditioned on changes of the business model, that is, they cannot be exclusively used to cover fixed costs, but to make transformative changes that enable the firm to generate higher profits in the future and hence to repay its debt, that is, a higher $\lambda_{N}{ }^{22}$

We use a firm-level survey of Swiss managers to confirm our model predictions. Specifically, we find that firms that faced a favorable business situation before the crisis are more likely to take up loans during the COVID-19 crisis. This implies that the Swiss economy is likely to be in a situation similar to case 1 in Figure 2. By adjusting the lockdown or the amount of guaranteed loans policy makers would be able to change the share of zombie firms and firms leaving the market. In this sense the policy makers have a trade-off between higher unemployment rates during the crisis and higher public spending after the crisis due to firms defaulting in their loans or an ex-post debt relief.

We also analyze firm-level responses during the COVID-19 crisis in more detail. We observe that during our survey most firms were still in a reactive crisis mode. Firms were not pro-actively changing their business model but tried to minimize costs by reducing their business activities or using short-time work. Only in the area of digitalization we find some long-term reactions. In the new normal firms will use more digital tools and specifically 
much more home office than before the COVID-19 crisis. In the light of the possible presence of zombie firms the firm-level responses seem to be insufficient to be able to generate long-term higher profits after the COVID-19 crisis. This would imply that the government only delays unemployment or is willing to finance a debt-relief for zombie firms.

\section{Supplementary material}

Supplementary material is available at Cesifo online.

\section{Acknowledgments}

The authors gratefully acknowledge numerous useful comments from two anonymous reviewers. We thank the Swiss federal economic expert group around Monika Bütler, Marius Brülhart, Rafael Lalive, David Dorn, and Jan-Egbert Sturm for their valuable comments, Beatrice Vogel for her excellent research assistance, and Michael Farley and Christian Graf for their support of the survey.

\section{References}

Altig, D., S. R. Baker, J. M. Barrero, N. Bloom, P. Bunn, S. Chen, S. J. Davis, J. Leather, B. H. Meyer, E. Mihaylov, P. Mizen, N. B. Parker, T. Renault, P. Smietanka, and G. Thwaites (2020), "Economic Uncertainty Before and During the COVID-19 Pandemic", Journal of Public Economics 191.

Anderson, J. E. and V. Y. Yoto (2010), “The Changing Incidence of Geography”, American Economic Review 100, 2157-86.

Aum, S., S. Y. (T.) Lee, and Y. Shin (2020), "Inequality of Fear and Self-quarantine: Is There a Trade-off between GDP and Public Health?”, NBER Working Papers, No 27100, National Bureau of Economic Research.

Baldwin, R. (2020), "The Supply Side Matters: Guns versus Butter, COVID-Style”, VoxEU, CEPR, 22 March.

Banerjee, R. and B. Hofmann (2018), "The Rise of Zombie Firms: Causes and Consequences”, BIS Quarterly Review September 2018, 12.

Baqaee, D. and E. Farhi (2020), "Supply and Demand in Disaggregated Keynesian Economies with an Application to the COVID-19 Crisis", CEPR Discussion Papers 14743.

Bargain, O. and U. Aminjonov (2020), "Trust and Compliance to Public Health Policies in Times of COVID-19", Bordeaux Economics Working Papers 2020-06, Groupe de Recherche en Economie Théorique et Appliquée (GREThA).

Barrios, J. M. and Y. Hochberg (2020), "Risk Perception through the Lens of Politics in the Time of the COVID-19 Pandemic”, NBER Working Papers, No 27008, National Bureau of Economic Research.

Bartik, A. W., M. Bertrand, Z. B. Cullen, E. L. Glaeser, M. Luca, and C. T. Stanton (2020), "How are Small Businesses Adjusting to COVID-19? Early Evidence from a Survey", HKS Faculty Research Working Paper Series RWP20-012.

Bethlehem, J. (2010), "Selection Bias in Web Surveys: Selection Bias in Web Surveys", International Statistical Review 78, 161-88.

Binder, C. (2020), "Coronavirus Fears and Macroeconomic Expectations", The Review of Economics and Statistics. 102, 721-30.

Blais, A., D. Bol, M. Giani, and P. J. Loewen (2020), “COVID-19 Lockdowns have Increased Support for Incumbents, Trust in Government, and Satisfaction with Democracy”, VoxEU, CEPR, 7 May. 
Bloom, N., P. Bunn, S. Chen, P. Mizen, P. Smietanka, and G. Thwaites (2019), "The Impact of Brexit on UK Firms”, Bank of England Working Papers 818, Bank of England.

Brülhart, M., J. Kläui, R. Lalive, T. Lehmann, and M. Siegenthaler (2020), Die Schweizer Selbständigerwerbenden im Covid19-Lockdown. mimeo.

Buchheim, L., J. Dovern, C. Krolage, and S. Link (2020), "Firm-level Expectations and Behavior in Response to the COVID-19 Crisis", CESifo Working Paper No. 8304, CESifo.

Burda, M. C. and A. Mertens (2001), "Estimating Wage Losses of Displaced Workers in Germany", Labour Economics 8, 15-41.

Caballero, R. J., T. Hoshi, and A. K. Kashyap (2008), "Zombie Lending and Depressed Restructuring in Japan”, American Economic Review 98, 1943-77.

Chaney, T. (2008), "Distorted Gravity: The Intensive and Extensive Margins of International Trade", American Economic Review 98, 1707-21.

Chaney, T. (2016), "Liquidity Constrained Exporters", Journal of Economic Dynamics and Control 72, 141-54.

Coveney, J. (2008), "FIRTHLOGIT: Stata Module to Calculate Bias Reduction in Logistic Regression", Working Paper Boston College Department of Economics.

Davidson, R. and J. G. MacKinnon (2004), Econometric Theory and Methods. Oxford University Press, Oxford, UK.

Dietrich, A., K. Kuester, G. Mueller, and R. Schoenle (2020), "News and Uncertainty about COVID-19: Survey Evidence and Short-run Economic Impact”, Working Paper No. 20-12, Federal Reserve Bank of Cleveland.

D'Orazio, M., M. D. Zio, and M. Scanu (2006), Statistical Matching: Theory and Practice. John Wiley \& Sons Ltd.

Edin, P.-A. and M. Gustavsson (2008), “Time Out of Work and Skill Depreciation”, ILR Review 61, 163-80.

Eichenauer, V. and J.-E. Sturm (2020), "Die Wirtschaftspolitischen Massnahmen der Schweiz zu Beginn der COVID-19-Pandemie”, Perspektiven der Wirtschaftspolitik 21, 290-300.

Eichenbaum, M. S., S. Rebelo, and M. Trabandt (2020), “The Macroeconomics of Epidemics”, NBER Working Papers 26882, National Bureau of Economic Research.

Ferguson, N. M., D. Laydon, G. Nedjati-Gilani, N. Imai, K. Ainslie, M. Baguelin, S. Bhatia, A. Boonyasiri, Z. Cucunuba, G. Cuomo-Dannenburg, A. Dighe, H. Fu, K. Gaythorpe, H. Thompson, R. Verity, E. Volz, H. Wang, Y. Wang, P. G. Walker, C. Walters, P. Winskill, C. Whittaker, C. A. Donnelly, S. Riley, and A. C. Ghani (2020), Report 9: Impact of Non-Pharmaceutical Interventions (NPIs) to Reduce COVID-19 Mortality and Healthcare Demand. mimeo.

Gentilini, U., M. Almenfi, P. Dale, J. Blomquist, R. Palacios, V. Desai, and V. Moreira (2020), "Social Protection and Jobs Responses to COVID-19: A Real-time Review of Country Measures", Working Paper, World Bank, Washington, DC.

Goodman-Bacon, A., and J. Marcus (2020), "Using Difference-in-Differences to Identify Causal Effects of COVID-19 Policies", 14, 153-8.

Gopinath, G., E. Helpman, and K. Rogoff (2014), Handbook of International Economics. Elsevier.

Gourinchas, P.-O. (2020), "Flatten the Curve of Infection and the Curve of Recession at the Same Time”, Foreign Affairs, 26 March.

Gregory, M. and R. Jukes (2001), “Unemployment and Subsequent Earnings: Estimating Scarring among British Men 1984-94”, The Economic Journal 111, 607-25.

Guerrieri, V., G. Lorenzoni, L. Straub, and I. Werning (2020), "Macroeconomic Implications of COVID-19: Can Negative Supply Shocks Cause Demand Shortages”, NBER Working Paper No. 26918, National Bureau of Economic Research.

Hale, T., A. Petherick, T. Philips, and S. Webster (2020), "Variation in Government Responses to COVID-19. Version 4.0”, Blavatnik School of Government Working Paper. 
Hamermesh, D. S. (1989), "What Do We Know about Worker Displacement in the U.S.?", Industrial Relations: A Journal of Economy and Society 28, 51-9.

Heckman, J. J. (1979), "Sample Selection Bias as a Specification Error", Econometrica 47, 153-61.

Kermack, W. O. and A. G. McKendrick (1927), "A Contribution to the Mathematical Theory of Epidemics", Proceedings of the Royal Society of London. Series A, Containing Papers of a Mathematical and Physical Character 115, 700-21.

KOF (2020), Executive Summary of KOF's Economic Forecast for Summer 2020. Swiss Economic Institute, ETH Zurich.

Kopp, D. and M. Siegenthaler (2018), “Does Short-time Work Prevent Unemployment?”, SECO Publikation Arbeitsmarktpolitik 49.

Lavrakas, P. J. (2008), Encyclopedia of Survey Research Methods, SAGE Publication.

Leduc, S. and Z. Liu (2020), "The Uncertainty Channel of the Coronavirus", FRBSF Economic Letter $1-5$.

Maloney, W. and T. Taskin (2020), "Determinants of Social Distancing and Economic Activity during COVID-19: A Global View”, Policy Research Working Papers 9242, The World Bank, Washington, DC.

Manova, K. (2013), "Credit Constraints, Heterogeneous Firms, and International Trade", The Review of Economic Studies 80, 711-44.

McGowan, M. A., D. Andrews, and V. Millot (2017), "Insolvency Regimes, Zombie Firms and Capital Reallocation”, OECD Economics Department Working Papers, No. 1399, OECD Publishing, Paris.

McGowan, M. A., D. Andrews, and V. Millot (2018), "The Walking Dead? Zombie Firms and Productivity Performance in OECD Countries”, Economic Policy 33, 685-736.

Melitz, M. J. (2003), "The Impact of Trade on Intra-industry Reallocations and Aggregate Industry Productivity", Econometrica 71, 1695-725.

OECD (2020), "OECD Policy Tracker", https://www.oecd.org/coronavirus/country-policytracker/

Pissarides, C. A. (1992), "Loss of Skill during Unemployment and the Persistence of Employment Shocks”, The Quarterly Journal of Economics 107, 1371-91.

Wooldridge, J. M. (2013), Introductory Econometrics: A Modern Approach, 5th edn. South-Western Cengage Learning. 


\section{Appendix A: Equilibrium Price Indices and Aggregated Profits}

To derive the equilibrium we follow Chaney (2008) for an economy in autarky, but allowing for a variable share parameter of the upper tier utility function. We assume that the productivity $a$ is Pareto distributed with an minimum $a_{L}$ and a shape parameter $\gamma>0$. The cutoffs were derived in Section 4. As in Chaney (2008) we assume that the mass of potential firms in the economy is proportional to the (exogenously) given population $L$ in the economy.

The price index in the economy in state $j=B, C, N$ is given by

$$
\begin{gathered}
P_{j}^{1-\epsilon}=L \int_{\zeta}^{\infty} p(a)^{1-\epsilon} d G(a), \\
=L \int_{\zeta}^{\infty}\left(\frac{\epsilon-1}{\epsilon} \frac{a}{c}\right)^{\epsilon-1} d G(a), \\
=L \frac{\gamma}{\gamma-(\epsilon-1)}\left(\frac{\epsilon-1}{\epsilon} \frac{1}{c}\right)^{\epsilon-1} \zeta^{\epsilon-1-\gamma},
\end{gathered}
$$

where $\zeta$ is the productivity cutoff for the corresponding state and case for firms to be present in the market as shown in Table 1 , that is, $\tilde{a}_{N}, \bar{a}_{C}$, and $\bar{a}_{N}$.

Substituting in the expression for the productivity cutoff and rearranging we can obtain the equilibrium solution for the price index as

$$
P_{j}^{1-\epsilon}=\kappa_{1} L^{-\frac{1}{\epsilon-1}} \theta
$$

where $\theta^{-\gamma}=\rho(\zeta)^{-(\gamma / \epsilon-1-1)}$ and $k_{1}=\left(\epsilon / \lambda_{j}\right)^{1 / \epsilon-1}(\epsilon / \epsilon-1)(1+\Pi / L) . \rho$ is a function of $\zeta$, which is either $f+M$ or $f-M$ if $\zeta=\bar{a}_{N}$ or $\zeta=\bar{a}_{C}$, respectively. To this end, we discard case 2, as a too high level of available credits is not very likely. ${ }^{23}$ Moreover, this facilitates the derivation of the cutoffs and equilibrium price indices. Specifically, only the cutoffs $\bar{a}_{C}$, and $\bar{a}_{N}$ are relevant. For these cutoffs the marginal firm always takes up the maximum amount of debt, $M$. This implies that Equation (11) simplifies to

$$
\pi_{N}\left(a, \lambda_{N}\right)=p(a) q\left(a, \lambda_{N}\right)-q\left(a, \lambda_{N}\right) \frac{c}{a}-(f+M)
$$

Now the solution of the model follows exactly Chaney (2008).

$$
r(a)=\kappa_{2} \theta^{\epsilon-1} a^{\epsilon-1} \quad \text { if } a \geq \zeta,
$$

and zero otherwise. Where $\kappa_{2}=\epsilon\left(\frac{\epsilon}{\lambda_{j}}\left(\gamma / \gamma-(\epsilon-1) 1 / 1+\kappa_{3}\right)\right)^{1-\epsilon}$ and $\kappa_{3}=\lambda_{j}(\epsilon-1) /$ $\gamma \epsilon-\lambda_{j}(\epsilon-1)$. The aggregate profits $\Pi$ are given by the marked-up average revenues multiplied by the number of firms in the market. This can be written in terms of exogenous parameters and the population size of the economy. we expect to observe a general up take of federal loans, and no firm is in a situation that would lead to immediate bankruptcy. 


$$
\Pi=\kappa_{3} L .
$$

Clearly, aggregate profits increase with the share parameter of the upper tier utility function, $\lambda_{j}$, that is, a better economic situation raises the aggregated profits in the economy.

\section{Appendix B: Descriptive Statistics}

Table B1. Descriptive statistics

\begin{tabular}{|c|c|c|c|c|c|}
\hline Variable & Obs. & Mean & Std. dev. & Min & Max \\
\hline Revenues & 193 & 3.51 & 1.83 & 1 & 6 \\
\hline Employees & 205 & 4.06 & 1.72 & 1 & 6 \\
\hline Business situation 2019 & 189 & 2.11 & 1.04 & -1 & 3 \\
\hline Business situation April 2020 & 189 & 0.5 & 1.9 & -3 & 3 \\
\hline Expected business situation & 189 & 0.06 & 1.98 & -3 & 3 \\
\hline Ban business activities & 154 & 2.82 & 1.5 & 1 & 7 \\
\hline Domestic demand & 170 & 2.95 & 1.34 & 0 & 8 \\
\hline Foreign demand & 145 & 3.06 & 1.17 & 1 & 7 \\
\hline Domestic supply & 152 & 3.81 & 1.19 & 1 & 7 \\
\hline Foreign supply & 152 & 3.2 & 1.16 & 1 & 7 \\
\hline Workers not at work place & 176 & 3.7 & 1.22 & 1 & 7 \\
\hline Finance problems & 164 & 3.43 & 1.5 & 1 & 7 \\
\hline Preparation & 175 & 3.34 & 1.56 & 1 & 6 \\
\hline Stop business & 183 & 0.14 & 0.35 & 0 & 1 \\
\hline Cost reduction or short-time work & 183 & 0.36 & 0.48 & 0 & 1 \\
\hline Reduce business & 183 & 0.3 & 0.46 & 0 & 1 \\
\hline Bundeshilfe or credits & 183 & 0.08 & 0.27 & 0 & 1 \\
\hline Cost reduction (Home Office) & 183 & 0.85 & 0.36 & 0 & 1 \\
\hline Change of business model & 181 & 0.06 & 0.23 & 0 & 1 \\
\hline New products/services & 181 & 0.13 & 0.34 & 0 & 1 \\
\hline Digitalization & 181 & 0.23 & 0.42 & 0 & 1 \\
\hline Delivery & 181 & 0.02 & 0.15 & 0 & 1 \\
\hline Expected peak timing & 189 & 2.42 & 1.11 & 1 & 5 \\
\hline Expected new normal timing & 191 & 3.73 & 1.19 & 1 & 6 \\
\hline
\end{tabular}

Note: Descriptive statistics of variables used. The survey questions are available in the Supplementary Appendix. 


\section{Appendix C: Sample and Population}

Table C1. Sector sample vs. population

\begin{tabular}{|c|c|c|c|}
\hline Sector & Sample share & Pop. share & Difference \\
\hline Construction & 0.1366 & 0.1030 & 0.0336 \\
\hline Chemical and pharmaceutical & 0.0634 & 0.0036 & 0.0598 \\
\hline Retail & 0.0293 & 0.0727 & -0.0434 \\
\hline Energy and water supply & 0.039 & 0.0045 & 0.0345 \\
\hline Other services & 0.0927 & 0.0922 & 0.0005 \\
\hline Education & 0.0439 & 0.0436 & 0.0003 \\
\hline Financial services & 0.0878 & 0.1171 & -0.0293 \\
\hline Hospitality & 0.0146 & 0.0639 & -0.0493 \\
\hline Health care & 0.0341 & 0.1437 & -0.1096 \\
\hline Wholesale & 0.0098 & 0.0488 & -0.0390 \\
\hline ICT & 0.0829 & 0.0377 & 0.0452 \\
\hline Recreation & 0.0098 & 0.0826 & -0.0728 \\
\hline Food and beverages & 0.0341 & 0.1111 & -0.0770 \\
\hline Manufacturing industry & 0.1854 & 0.0095 & 0.1759 \\
\hline Public administration & 0.0439 & 0.0263 & 0.0176 \\
\hline Logistics & 0.0829 & 0.0053 & 0.0776 \\
\hline Others & 0.0098 & 0.0059 & 0.0039 \\
\hline
\end{tabular}

Note: Comparison of share of firms by sector in the sample and the population.

Table C2. Firm size sample vs. population

\begin{tabular}{lccr}
\hline Sector & Sample share & Pop. share & Difference \\
\hline 1-9 employees & 0.1902 & 0.8834 & -0.6932 \\
10-49 employees & 0.1561 & 0.0948 & 0.0613 \\
50-249 employees & 0.2098 & 0.0184 & 0.1914 \\
More than 250 employees & 0.4439 & 0.0035 & 0.4404 \\
\hline
\end{tabular}

Note: Comparison of share of firms by size in the sample and the population. 
Table C3. Firm location sample vs. population

\begin{tabular}{|c|c|c|c|}
\hline Canton & Sample share & Pop. share & Difference \\
\hline Aargau & 0.0552 & 0.0666 & -0.0114 \\
\hline Appenzell Aus. & 0.0000 & 0.0072 & -0.0072 \\
\hline Appenzell Inn. & 0.0000 & 0.0022 & -0.0022 \\
\hline Basel-Landschaft & 0.0061 & 0.0297 & -0.0236 \\
\hline Basel-Stadt & 0.0123 & 0.0267 & -0.0144 \\
\hline Bern & 0.0736 & 0.1067 & -0.0331 \\
\hline Freiburg & 0.0000 & 0.0293 & -0.0293 \\
\hline Genf & 0.0245 & 0.0652 & -0.0407 \\
\hline Glarus & 0.0000 & 0.0045 & -0.0045 \\
\hline Graubünden & 0.0184 & 0.0275 & -0.0091 \\
\hline Jura & 0.0000 & 0.0082 & -0.0082 \\
\hline Luzern & 0.0491 & 0.0435 & 0.0056 \\
\hline Neuenburg & 0.0000 & 0.0199 & -0.0199 \\
\hline Nidwalden & 0.0000 & 0.0059 & -0.0059 \\
\hline Obwalden & 0.0000 & 0.0048 & -0.0048 \\
\hline Schaffhausen & 0.0000 & 0.0093 & -0.0093 \\
\hline Schwyz & 0.0123 & 0.0229 & -0.0106 \\
\hline Solothurn & 0.0000 & 0.0262 & -0.0262 \\
\hline St. Gallen & 0.0491 & 0.0543 & -0.0052 \\
\hline Tessin & 0.0123 & 0.0629 & -0.0506 \\
\hline Thurgau & 0.0307 & 0.0286 & 0.0021 \\
\hline Uri & 0.0000 & 0.0033 & -0.0033 \\
\hline Waadt & 0.0123 & 0.0892 & -0.0769 \\
\hline Wallis & 0.0000 & 0.0417 & -0.0417 \\
\hline Zug & 0.0123 & 0.0294 & -0.0171 \\
\hline Zürich & 0.6196 & 0.1845 & 0.4351 \\
\hline
\end{tabular}

Note: Comparison of share of firms by canton in the sample and the population. 


\section{Appendix D: Robustness: Canton Fixed Effects}

Table D1. Estimation: business situation

\begin{tabular}{|c|c|c|c|c|c|c|}
\hline & \multicolumn{3}{|c|}{ April 2020} & \multicolumn{3}{|c|}{ Expected peak COVID } \\
\hline & $\begin{array}{c}\text { Problems } \\
\text { (1) }\end{array}$ & $\begin{array}{l}\text { Reaction } \\
\text { (2) }\end{array}$ & $\begin{array}{l}\text { All } \\
(3)\end{array}$ & $\begin{array}{c}\text { Problems } \\
\text { (4) }\end{array}$ & $\begin{array}{c}\text { Reaction } \\
(5)\end{array}$ & $\begin{array}{l}\text { All } \\
(6)\end{array}$ \\
\hline \multirow[t]{2}{*}{ Employees } & 0.345 & $0.455^{*}$ & 0.492 & 0.465 & $0.495^{*}$ & 0.637 \\
\hline & $(0.448)$ & $(0.268)$ & $(0.471)$ & $(0.477)$ & $(0.284)$ & $(0.526)$ \\
\hline \multirow[t]{2}{*}{ Revenues } & -0.123 & -0.185 & -0.397 & -0.170 & -0.111 & -0.405 \\
\hline & $(0.474)$ & $(0.253)$ & $(0.463)$ & $(0.506)$ & $(0.268)$ & $(0.518)$ \\
\hline \multirow[t]{2}{*}{ Ban business activities } & -0.062 & & -0.192 & 0.098 & & -0.113 \\
\hline & $(0.227)$ & & $(0.288)$ & $(0.242)$ & & $(0.322)$ \\
\hline \multirow[t]{2}{*}{ Domestic demand } & 0.327 & & 0.173 & 0.131 & & -0.085 \\
\hline & $(0.231)$ & & $(0.225)$ & $(0.246)$ & & $(0.252)$ \\
\hline \multirow[t]{2}{*}{ Foreign demand } & 0.392 & & 0.434 & 0.476 & & $0.606^{*}$ \\
\hline & $(0.276)$ & & $(0.292)$ & $(0.294)$ & & $(0.327)$ \\
\hline \multirow[t]{2}{*}{ Domestic supply } & -0.233 & & -0.087 & -0.103 & & 0.102 \\
\hline & $(0.239)$ & & $(0.259)$ & $(0.255)$ & & $(0.289)$ \\
\hline \multirow[t]{2}{*}{ Foreign supply } & 0.277 & & 0.062 & 0.006 & & -0.244 \\
\hline & $(0.276)$ & & $(0.287)$ & $(0.295)$ & & $(0.321)$ \\
\hline \multirow[t]{2}{*}{ Workers at home } & -0.023 & & -0.128 & -0.145 & & -0.306 \\
\hline & $(0.220)$ & & $(0.229)$ & $(0.234)$ & & $(0.256)$ \\
\hline \multirow[t]{2}{*}{ Finance } & 0.172 & & 0.137 & 0.158 & & 0.056 \\
\hline & $(0.202)$ & & $(0.208)$ & $(0.215)$ & & $(0.233)$ \\
\hline \multirow[t]{2}{*}{ Preparation } & & 0.097 & 0.025 & & 0.160 & 0.105 \\
\hline & & $(0.113)$ & $(0.162)$ & & $(0.119)$ & $(0.182)$ \\
\hline \multirow[t]{2}{*}{ Stop business } & & $-1.280^{* *}$ & -0.846 & & -0.939 & -0.308 \\
\hline & & $(0.606)$ & $(0.833)$ & & $(0.641)$ & $(0.932)$ \\
\hline \multirow[t]{2}{*}{ Cost reduction } & & $-1.162^{* *}$ & $-1.537^{* *}$ & & -0.769 & -1.460 \\
\hline & & $(0.448)$ & $(0.649)$ & & $(0.473)$ & $(0.726)$ \\
\hline \multirow[t]{2}{*}{ Reduce business } & & 0.150 & 0.167 & & 0.272 & -0.093 \\
\hline & & $(0.405)$ & $(0.623)$ & & $(0.428)$ & $(0.696)$ \\
\hline \multirow[t]{2}{*}{ Bundeshilfe or credits } & & $-1.544^{* * *}$ & -1.813 & & $-1.643^{* * *}$ & -2.171 \\
\hline & & $(0.728)$ & $(1.159)$ & & $(0.769)$ & $(1.296)$ \\
\hline \multirow[t]{2}{*}{ Home Office } & & 0.048 & 0.554 & & -0.275 & 0.213 \\
\hline & & $(0.623)$ & $(0.904)$ & & $(0.658)$ & $(1.010)$ \\
\hline \multirow[t]{2}{*}{ Change of BM } & & -0.423 & -1.103 & & -0.335 & -1.734 \\
\hline & & $(1.172)$ & $(1.486)$ & & $(1.238)$ & (1.661) \\
\hline \multirow[t]{2}{*}{ New products/services } & & -0.345 & -1.638 & & -0.277 & -1.369 \\
\hline & & $(0.578)$ & $(1.070)$ & & $(0.611)$ & $(1.196)$ \\
\hline \multirow[t]{2}{*}{ Digitalization } & & 0.098 & 0.648 & & 0.111 & 0.979 \\
\hline & & $(0.465)$ & $(0.626)$ & & $(0.491)$ & $(0.700)$ \\
\hline \multirow[t]{2}{*}{ Delivery } & & -0.572 & 0.704 & & -1.326 & 0.416 \\
\hline & & $(1.711)$ & $(2.031)$ & & $(1.808)$ & $(2.271)$ \\
\hline Obs. & 79 & 120 & 76 & 80 & 120 & 76 \\
\hline Adj. $R^{2}$ & 0.246 & 0.327 & 0.379 & 0.218 & 0.331 & 0.295 \\
\hline
\end{tabular}

Notes: Fixed effect estimation of the current and expected business situation. Sector fixed effects, canton fixed effects, survey time fixed effects, and MNE fixed effects. Robust standard errors clustered at the sector level in parentheses. *p, ${ }^{* *}$, and $* *$ denote statistical significance at the $10 \%, 5 \%$, and $1 \%$ level, respectively. 
Table D2. Estimation: federal loan take up

\begin{tabular}{lcccc}
\hline & $(1)$ & $(2)$ & $(3)$ & $(4)$ \\
\hline Employees & 0.008 & 0.030 & 0.042 & 0.043 \\
& $(0.041)$ & $(0.055)$ & $(0.055)$ & $(0.054)$ \\
Revenues & -0.039 & -0.042 & -0.040 & -0.043 \\
& $(0.039)$ & $(0.055)$ & $(0.054)$ & $(0.053)$ \\
Domestic demand & & -0.046 & -0.024 & -0.023 \\
& & $(0.028)$ & $(0.029)$ & $(0.029)$ \\
Foreign demand & & 0.001 & 0.016 & 0.16 \\
& & $(0.030)$ & $(0.030)$ & $(0.029)$ \\
Business situation 2019 & 0.027 & 0.014 & 0.042 & \\
Business situation April 2020 & $(0.028)$ & $(0.036)$ & $(0.037)$ & \\
Business situation peak & & & -0.034 & \\
Diff. 2019 and April 2020 & & & $(0.039)$ & \\
Diff. April 2020 and peak & & & -0.020 & $(0.036)$ \\
& & & & $0.052^{* * *}$ \\
\hline Obs. & & & & $(0.019)$ \\
Adj. $R^{2}$ & & & & 0.018 \\
\hline
\end{tabular}

Notes: Linear probability model. Sector fixed effects, canton fixed effect, survey time fixed effects, and MNE fixed effects. Robust standard errors clustered at the sector level in parenthesis. *, **, and * denote statistical significance at the $10 \%, 5 \%$, and $1 \%$ level, respectively. 
Table D3. Estimation: short-time work take up

\begin{tabular}{lcccc}
\hline & $(1)$ & $(2)$ & $(3)$ & $(4)$ \\
\hline Employees & 0.032 & 0.118 & 0.118 & 0.125 \\
Revenues & $(0.070)$ & $(0.088)$ & $(0.089)$ & $(0.088)$ \\
& -0.009 & -0.114 & -0.096 & -0.108 \\
Domestic demand & $(0.067)$ & $(0.089)$ & $(0.088)$ & $(0.087)$ \\
& & -0.047 & -0.005 & -0.004 \\
Foreign demand & & $(0.046)$ & $(0.047)$ & $(0.047)$ \\
& & -0.057 & -0.040 & -0.054 \\
Business situation 2019 & -0.023 & $(0.049)$ & $(0.048)$ & $(0.047)$ \\
Business situation April 2020 & $(0.048)$ & -0.026 & 0.021 & $(0.059)$ \\
Business situation peak & & & -0.104 & $(0.063)$ \\
Diff. 2019 and April 2020 & & & 0.022 & $(0.059)$ \\
Diff. April 2020 and peak & & & & 0.614 \\
\hline Obs. $R^{2}$ & & & & $(0.032)$ \\
\hline
\end{tabular}

Notes: Linear probability model. Sector fixed effects, canton fixed effect, survey time fixed effects, and MNE fixed effects. Robust standard errors clustered at the sector level in parenthesis. $* * * * *$, and * denote statistical significance at the $1 \%, 5 \%$, and $10 \%$ level, respectively. 


\section{Appendix E: Robustness: Probit and Logit Estimations}

Table E1 presents the results from a probit estimation. These are qualitative similar to the estimation results given by the linear probability model in Table 4. A more favorable assessment of the past business environment increases the probability to take up loans.

Similarly, a more severe drop between the current business situation relative to the one in 2019 also increases the probability to take up federal loans. The same holds for the difference between the current and expected business situation at the peak economic impact of the COVID-19 pandemic. We plot the marginal effects for the estimates of the 2019 business situation in column (3) and the difference between the 2019 and current business situation given in column (4) in Appendix Figure E1. The point estimates of the probit model for the past business situation and the change of the business situation are consistent with the ones of the linear probability model presented in Table 4.

The probability to take up a federal loan clearly increases with the managers' assessment of the 2019 business situation. The same holds for a more pronounced drop of the business situation between 2019 and April 2020.

We estimate also a logistic probability model. The standard maximum likelihood estimation does not converge, thus we use a penalized maximum likelihood estimator suggested

Table E1. Probit estimation: federal loan take up

\begin{tabular}{lcccc}
\hline & $(1)$ & $(2)$ & $(3)$ & $(4)$ \\
\hline Employees & 0.260 & $0.654^{*}$ & $1.145^{* * *}$ & $1.113^{* *}$ \\
& $(0.323)$ & $(0.376)$ & $(0.538)$ & $(0.588)$ \\
Revenues & -0.479 & $-0.767^{*}$ & $-1.200^{* *}$ & $-1.177^{* *}$ \\
& $(0.332)$ & $(0.394)$ & $(0.539)$ & $(0.579)$ \\
Domestic demand & & $-0.412^{* *}$ & -0.204 & -0.212 \\
& & $(0.211)$ & $(0.232)$ & $(0.231)$ \\
Foreign demand & & -0.230 & 0.107 & 0.079 \\
& & $(0.248)$ & $(0.257)$ & $(0.273)$ \\
Business situation 2019 & $0.383^{*}$ & 0.377 & $0.537^{* *}$ & \\
Business situation April 2020 & $(0.230)$ & $(0.247)$ & $(0.269)$ & \\
Business situation peak & & & -0.043 & \\
Diff. 2019 and April 2020 & & & $-0.213)$ & \\
Diff. April 2020 and peak & & & $(0.227)$ & \\
& & & & $0.572^{* * *}$ \\
\hline Obs. & & & & $(0.185)$ \\
Pseudo $R^{2}$ & & & & $0.535^{* * *}$ \\
\hline
\end{tabular}

Notes: Probit probability model. Sector fixed effects, survey time fixed effects, and MNE fixed effects. Robust standard errors clustered at the sector level in parenthesis. $* * * *$, and $*$ denote statistical significance at the $1 \%, 5 \%$, and $10 \%$ level, respectively. 


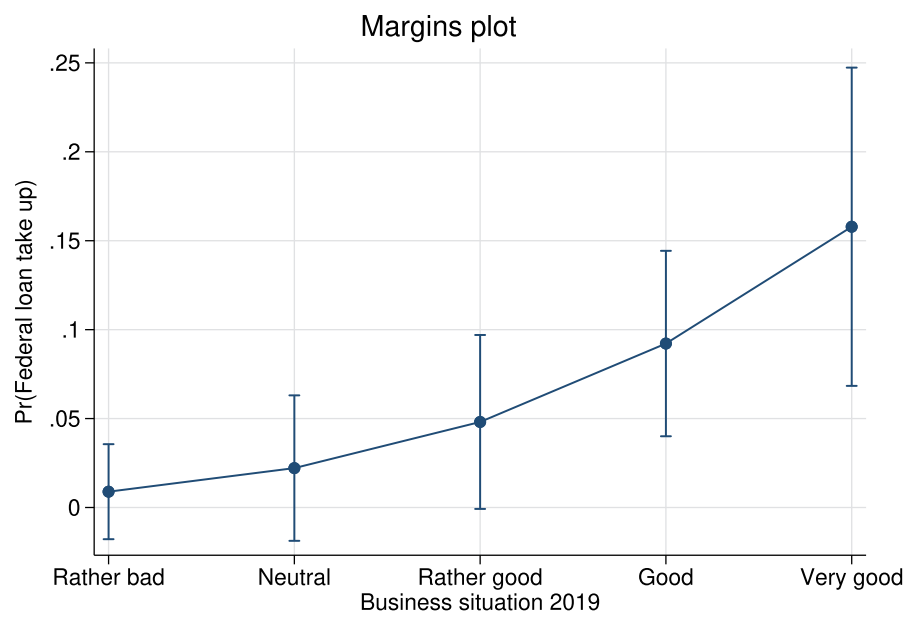

(a) Business situation 2019

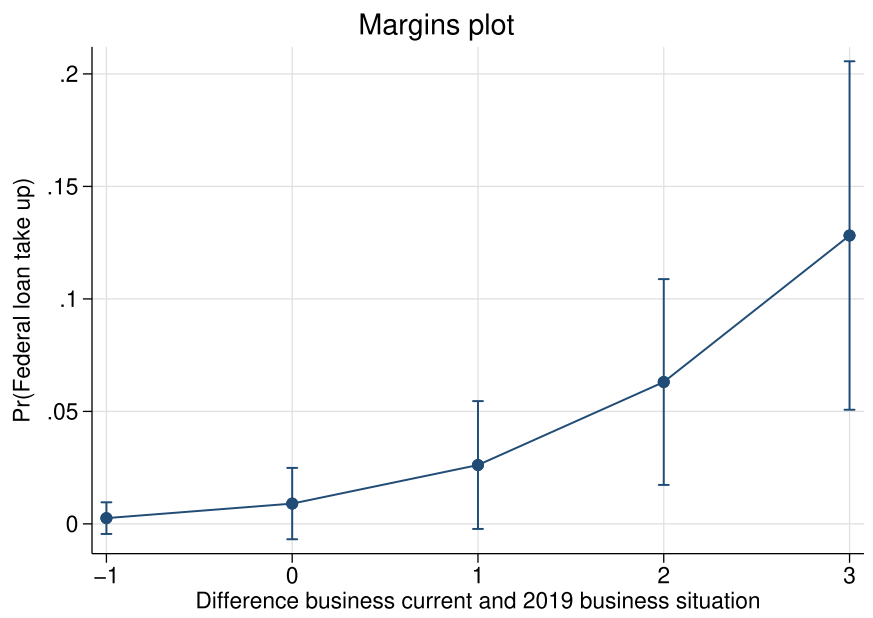

\section{(b) Difference 2019 and current business situation}

Figure E1. Marginal effect plots with 95\% confidence intervals based on columns (3) and (4) estimates in Table E1.

by Coveney (2008) for logistics regressions with rare events. The estimation results are shown in Table E2.

In this estimation the past business situation has never a statistical significant effect, see columns (1)-(3). In column (4) the change in the business situation has a positive effect qualitatively similar to the linear probability model in Table 4 and the probit model in Table E1. The marginal effects are also increasing with the perceived change between 2019 and April 2020, but the base line probabilities are negative. Logistics regressions perform rather poorly in estimations with rare events and small sample sizes. Hence, we prefer the 
Table E2. Logit estimation: federal loan take up

\begin{tabular}{|c|c|c|c|c|}
\hline & (1) & (2) & (3) & (4) \\
\hline \multirow[t]{2}{*}{ Employees } & 0.406 & 0.683 & 0.755 & 0.813 \\
\hline & $(0.499)$ & $(0.641)$ & $(0.690)$ & $(0.706)$ \\
\hline \multirow[t]{2}{*}{ Revenues } & -0.714 & -0.841 & -0.868 & -0.919 \\
\hline & $(0.503)$ & $(0.620)$ & $(0.665)$ & $(0.683)$ \\
\hline \multirow[t]{2}{*}{ Domestic demand } & & -0.447 & -0.203 & -0.211 \\
\hline & & $(0.387)$ & $(0.410)$ & $(0.420)$ \\
\hline \multirow[t]{2}{*}{ Foreign demand } & & -0.196 & 0.107 & 0.146 \\
\hline & & $(0.452)$ & $(0.460)$ & $(0.434)$ \\
\hline \multirow[t]{2}{*}{ Business situation 2019} & 0.504 & 0.409 & 0.518 & \\
\hline & $(0.391)$ & $(0.412)$ & $(0.410)$ & \\
\hline \multirow[t]{2}{*}{ Business situation April 2020} & & & -0.057 & \\
\hline & & & $(0.432)$ & \\
\hline \multirow[t]{2}{*}{ Business situation peak } & & & -0.401 & \\
\hline & & & $(0.453)$ & \\
\hline \multirow[t]{2}{*}{ Diff. 2019 and April 2020} & & & & $0.513^{*}$ \\
\hline & & & & $(0.284)$ \\
\hline \multirow[t]{2}{*}{ Diff. April 2020 and peak } & & & & 0.435 \\
\hline & & & & $(0.451)$ \\
\hline Obs. & 169 & 132 & 130 & 130 \\
\hline Pseudo $R^{2}$ & 0.21 & 0.27 & 0.38 & 0.39 \\
\hline
\end{tabular}

Notes: Logit probability model. Sector fixed effects, survey time fixed effects, and MNE fixed effects. Robust standard errors clustered at the sector level in parenthesis. $* * * *$, and $*$ denote statistical significance at the $1 \%, 5 \%$, and $10 \%$ level, respectively.

linear probability and probit models to estimate the impact of the business situation on the take up of federal loans.

Tables E3 and E4 show the results of a probit and tobit models estimation for the shorttime work take up.

The results are qualitatively similar to the linear probability model presented in Table 5 . The business situation in 2019 does not have any significant impact on the take up of shorttime work programs by the firms, only the worsening of the business situation between 2019 and April 2020 does have a significant impact. 
Table E3. Probit estimation: short-time work take up

\begin{tabular}{|c|c|c|c|c|}
\hline & (1) & (2) & (3) & (4) \\
\hline Employees & $\begin{array}{c}0.098 \\
(0.179)\end{array}$ & $\begin{array}{c}0.312 \\
(0.232)\end{array}$ & $\begin{array}{c}0.321 \\
(0.246)\end{array}$ & $\begin{array}{c}0.375 \\
(0.248)\end{array}$ \\
\hline Revenues & $\begin{array}{c}0.020 \\
(0.169)\end{array}$ & $\begin{array}{l}-0.182 \\
(0.226)\end{array}$ & $\begin{array}{l}-0.139 \\
(0.241)\end{array}$ & $\begin{array}{l}-0.211 \\
(0.241)\end{array}$ \\
\hline Domestic demand & & $\begin{array}{l}-0.195 \\
(0.129)\end{array}$ & $\begin{array}{l}-0.089 \\
(0.128)\end{array}$ & $\begin{array}{l}-0.091 \\
(0.137)\end{array}$ \\
\hline Foreign demand & & $\begin{array}{c}-0.453^{* *} \\
(0.178)\end{array}$ & $\begin{array}{c}-0.320^{*} \\
(0.183)\end{array}$ & $\begin{array}{c}-0.409^{* *} \\
(0.178)\end{array}$ \\
\hline Business situation 2019 & $\begin{array}{l}-0.110 \\
(0.112)\end{array}$ & $\begin{array}{l}-0.137 \\
(0.136)\end{array}$ & $\begin{array}{c}-0.035 \\
(0.142)\end{array}$ & \\
\hline Business situation April 2020 & & & $\begin{array}{c}-0.265^{*} \\
(0.159)\end{array}$ & \\
\hline Business situation peak & & & $\begin{array}{c}0.018 \\
(0.137)\end{array}$ & \\
\hline Diff. 2019 and April 2020 & & & & $\begin{array}{l}0.191^{* *} \\
(0.089)\end{array}$ \\
\hline Diff. April 2020 and peak & & & & $\begin{array}{l}-0.023 \\
(0.137)\end{array}$ \\
\hline Obs. & 164 & 128 & 126 & 126 \\
\hline Pseudo $R^{2}$ & 0.20 & 0.29 & 0.33 & 0.31 \\
\hline
\end{tabular}

Notes: Probit model. Sector fixed effects, survey time fixed effects, and MNE fixed effects. Robust standard errors clustered at the sector level in parenthesis. $* * * *$, and $*$ denote statistical significance at the $1 \%, 5 \%$, and $10 \%$ level, respectively. 
Table E4. Logit estimation: short-time work take up

\begin{tabular}{|c|c|c|c|c|}
\hline & (1) & $(2)$ & (3) & (4) \\
\hline Employees & $\begin{array}{c}0.122 \\
(0.277)\end{array}$ & $\begin{array}{c}0.424 \\
(0.356)\end{array}$ & $\begin{array}{c}0.432 \\
(0.365)\end{array}$ & $\begin{array}{c}0.511 \\
(0.361)\end{array}$ \\
\hline Revenues & $\begin{array}{c}0.042 \\
(0.269)\end{array}$ & $\begin{array}{l}-0.251 \\
(0.352)\end{array}$ & $\begin{array}{r}-0.198 \\
(0.366)\end{array}$ & $\begin{array}{l}-0.298 \\
(0.354)\end{array}$ \\
\hline Domestic demand & & $\begin{array}{l}-0.235 \\
(0.191)\end{array}$ & $\begin{array}{l}-0.079 \\
(0.198)\end{array}$ & $\begin{array}{l}-0.089 \\
(0.199)\end{array}$ \\
\hline Foreign demand & & $\begin{array}{c}-0.651^{* *} \\
(0.286)\end{array}$ & $\begin{array}{l}-0.446 \\
(0.295)\end{array}$ & $\begin{array}{c}-0.575^{* * *} \\
(0.283)\end{array}$ \\
\hline Business situation 2019 & $\begin{array}{l}-0.154 \\
(0.180)\end{array}$ & $\begin{array}{l}-0.192 \\
(0.221)\end{array}$ & $\begin{array}{l}-0.042 \\
(0.236)\end{array}$ & \\
\hline Business situation April 2020 & & & $\begin{array}{l}-0.361 \\
(0.257)\end{array}$ & \\
\hline Business situation peak & & & $\begin{array}{c}0.022 \\
(0.226)\end{array}$ & \\
\hline Diff. 2019 and April 2020 & & & & $\begin{array}{l}0.264^{*} \\
(0.142)\end{array}$ \\
\hline Diff. April 2020 and peak & & & & $\begin{array}{l}-0.029 \\
(0.224)\end{array}$ \\
\hline Obs. & 169 & 132 & 130 & 130 \\
\hline Pseudo $R^{2}$ & 0.18 & 0.26 & 0.32 & 0.29 \\
\hline
\end{tabular}

Notes: Logit probability model. Sector fixed effects, survey time fixed effects, and MNE fixed effects. Robust standard errors clustered at the sector level in parenthesis. $* * * *$, and $*$ denote statistical significance at the $1 \%, 5 \%$, and $10 \%$ level, respectively. 


\section{Appendix F: Robustness: Heterogeneous Effects}

Tables F1 and F2 analyze heterogeneous effects in terms of firm characteristics on the take up probability of federal guaranteed loans and short-time work, respectively. We split the sample into a service sector and an industrial sector. We define the construction, chemical, pharmaceutical, energy, food and beverage, and general manufacturing as industry sector. All other sectors are defined as service sector, for example, financial services, retail, or transportation and logistics.

Table F1 indicates that the domestic demand is in particular important for service firms, which are usually consumed locally, that is, a higher domestic demand for services decreases the probability to apply for federal loans. A better business situation in 2019 makes the take up of federal loans significantly more likely for service firms, but not for industrial firms. However, a greater drop in the business situation raises the probability for firms in the industry sector, see column (3). The business situation in 2019 does not have any significant different impact on the take up rate for small or big firms, but big firms with more than 50 employees react stronger on drop in the business situation between 2019 and April 2020.

Table F1. Estimation: federal loans heterogeneous effects

\begin{tabular}{|c|c|c|c|c|c|c|c|c|}
\hline & $\begin{array}{c}\text { Industry } \\
\text { (1) }\end{array}$ & $\begin{array}{c}\text { Service } \\
\text { (2) }\end{array}$ & $\begin{array}{c}\text { Industry } \\
\text { (3) }\end{array}$ & $\begin{array}{c}\text { Service } \\
\text { (4) }\end{array}$ & $\begin{array}{l}\text { Small } \\
(5)\end{array}$ & $\begin{array}{r}\text { Big } \\
(6)\end{array}$ & $\begin{array}{c}\text { Small } \\
(7)\end{array}$ & $\begin{array}{r}\text { Big } \\
(8)\end{array}$ \\
\hline Employees & $\begin{array}{c}0.006 \\
(0.069)\end{array}$ & $\begin{array}{c}0.066 \\
(0.048)\end{array}$ & $\begin{array}{c}0.006 \\
(0.050)\end{array}$ & $\begin{array}{c}0.063 \\
(0.042)\end{array}$ & $\begin{array}{c}0.170 \\
(0.145)\end{array}$ & $\begin{array}{r}-0.034 \\
(0.043)\end{array}$ & $\begin{array}{c}0.169 \\
(0.138)\end{array}$ & $\begin{array}{l}-0.033 \\
(0.040)\end{array}$ \\
\hline Revenues & $\begin{array}{l}-0.018 \\
(0.072)\end{array}$ & $\begin{array}{l}-0.075 \\
(0.047)\end{array}$ & $\begin{array}{l}-0.019 \\
(0.048)\end{array}$ & $\begin{array}{r}-0.058 \\
(0.051)\end{array}$ & $\begin{array}{l}-0.132 \\
(0.199)\end{array}$ & $\begin{array}{c}0.001 \\
(0.032)\end{array}$ & $\begin{array}{l}-0.131 \\
(0.193)\end{array}$ & $\begin{array}{r}-0.001 \\
(0.027)\end{array}$ \\
\hline Domestic demand & $\begin{array}{c}0.017 \\
(0.031)\end{array}$ & $\begin{array}{c}-0.064^{*} \\
(0.034)\end{array}$ & $\begin{array}{c}0.017 \\
(0.025)\end{array}$ & $\begin{array}{c}-0.053^{*} \\
(0.030)\end{array}$ & $\begin{array}{l}-0.039 \\
(0.046)\end{array}$ & $\begin{array}{c}0.005 \\
(0.019)\end{array}$ & $\begin{array}{l}-0.039 \\
(0.045)\end{array}$ & $\begin{array}{c}0.005 \\
(0.019)\end{array}$ \\
\hline Foreign demand & $\begin{array}{l}-0.016 \\
(0.039)\end{array}$ & $\begin{array}{c}0.16 \\
(0.039)\end{array}$ & $\begin{array}{l}-0.019 \\
(0.022)\end{array}$ & $\begin{array}{c}0.050 \\
(0.033)\end{array}$ & $\begin{array}{c}0.017 \\
(0.096)\end{array}$ & $\begin{array}{c}0.012 \\
(0.019)\end{array}$ & $\begin{array}{c}0.018 \\
(0.098)\end{array}$ & $\begin{array}{c}0.009 \\
(0.020)\end{array}$ \\
\hline Business situation 2019 & $\begin{array}{c}0.063 \\
(0.039)\end{array}$ & $\begin{array}{l}0.100^{* *} \\
(0.039)\end{array}$ & & & $\begin{array}{c}0.055 \\
(0.124)\end{array}$ & $\begin{array}{c}0.034 \\
(0.031)\end{array}$ & & \\
\hline Business situation April & $\begin{array}{l}-0.052 \\
(0.052)\end{array}$ & $\begin{array}{c}0.008 \\
(0.036)\end{array}$ & & & $\begin{array}{l}-0.022 \\
(0.079)\end{array}$ & $\begin{array}{l}-0.035 \\
(0.024)\end{array}$ & & \\
\hline Business situation peak & $\begin{array}{l}-0.018 \\
(0.046)\end{array}$ & $\begin{array}{l}-0.019 \\
(0.034)\end{array}$ & & & $\begin{array}{l}-0.026 \\
(0.082)\end{array}$ & $\begin{array}{l}-0.010 \\
(0.018)\end{array}$ & & \\
\hline Diff. 2019 and April 2020 & & & $\begin{array}{l}0.069^{* *} \\
(0.028)\end{array}$ & $\begin{array}{c}0.027 \\
(0.019)\end{array}$ & & & $\begin{array}{c}0.048 \\
(0.052)\end{array}$ & $\begin{array}{l}0.042^{* *} \\
(0.020)\end{array}$ \\
\hline Diff. April 2020 and peak & & & $\begin{array}{c}0.018 \\
(0.040)\end{array}$ & $\begin{array}{c}0.024 \\
(0.036)\end{array}$ & & & $\begin{array}{c}0.025 \\
(0.078)\end{array}$ & $\begin{array}{c}0.010 \\
(0.018)\end{array}$ \\
\hline Obs. & 60 & 70 & 60 & 70 & 42 & 88 & 42 & 88 \\
\hline Adj. $R^{2}$ & 0.338 & 0.319 & 0.338 & 0.258 & 0.449 & 0.298 & 0.449 & 0.296 \\
\hline
\end{tabular}

Notes: Linear probability model. Sector fixed effects, survey time fixed effects, and MNE fixed effects. Sample split into service sectors and industry (manufacturing) in columns (1)-(4), sample split into small firms (less than 50 employees) and big firms (more than 50 employees) in columns (5)-(8). Robust standard errors clustered at the sector level in parenthesis. $* * * *$, and ${ }^{*}$ denote statistical significance at the $1 \%, 5 \%$, and $10 \%$ level, respectively. 
Table F2. Estimation: short-time work heterogeneous effects

\begin{tabular}{|c|c|c|c|c|c|c|c|c|}
\hline & $\begin{array}{c}\text { Industry } \\
\text { (1) }\end{array}$ & $\begin{array}{c}\text { Service } \\
(2)\end{array}$ & $\begin{array}{c}\text { Industry } \\
\text { (3) }\end{array}$ & $\begin{array}{c}\text { Service } \\
(4)\end{array}$ & $\begin{array}{c}\text { Small } \\
(5)\end{array}$ & $\begin{array}{l}\text { Big } \\
(6)\end{array}$ & $\begin{array}{c}\text { Small } \\
(7)\end{array}$ & $\begin{array}{l}\text { Big } \\
(8)\end{array}$ \\
\hline Employees & $\begin{array}{c}0.060 \\
(0.107)\end{array}$ & $\begin{array}{c}0.076 \\
(0.098)\end{array}$ & $\begin{array}{c}0.067 \\
(0.089)\end{array}$ & $\begin{array}{c}0.079 \\
(0.105)\end{array}$ & $\begin{array}{c}0.026 \\
(0.148)\end{array}$ & $\begin{array}{c}0.048 \\
(0.088)\end{array}$ & $\begin{array}{c}0.029 \\
(0.141)\end{array}$ & $\begin{array}{c}0.054 \\
(0.088)\end{array}$ \\
\hline Revenues & $\begin{array}{c}0.022 \\
(0.111)\end{array}$ & $\begin{array}{l}-0.019 \\
(0.096)\end{array}$ & $\begin{array}{c}0.013 \\
(0.103)\end{array}$ & $\begin{array}{l}-0.030 \\
(0.097)\end{array}$ & $\begin{array}{c}0.293 \\
(0.234)\end{array}$ & $\begin{array}{r}-0.044 \\
(0.077)\end{array}$ & $\begin{array}{c}0.291 \\
(0.229)\end{array}$ & $\begin{array}{l}-0.054 \\
(0.075)\end{array}$ \\
\hline Domestic demand & $\begin{array}{l}-0.026 \\
(0.048)\end{array}$ & $\begin{array}{l}-0.030 \\
(0.069)\end{array}$ & $\begin{array}{r}-0.030 \\
(0.050)\end{array}$ & $\begin{array}{c}-0.038 \\
(0.067)\end{array}$ & $\begin{array}{c}0.067 \\
(0.094)\end{array}$ & $\begin{array}{l}-0.056 \\
(0.046)\end{array}$ & $\begin{array}{c}0.067 \\
(0.092)\end{array}$ & $\begin{array}{l}-0.061 \\
(0.047)\end{array}$ \\
\hline Foreign demand & $\begin{array}{l}-0.064 \\
(0.059)\end{array}$ & $\begin{array}{l}-0.072 \\
(0.079)\end{array}$ & $\begin{array}{c}-0.097^{*} \\
(0.055)\end{array}$ & $\begin{array}{r}-0.078 \\
(0.078)\end{array}$ & $\begin{array}{c}0.001 \\
(0.153)\end{array}$ & $\begin{array}{c}-0.093^{*} \\
(0.051)\end{array}$ & $\begin{array}{l}-0.001 \\
(0.154)\end{array}$ & $\begin{array}{c}-0.108^{* * *} \\
(0.050)\end{array}$ \\
\hline Business situation 2019 & $\begin{array}{c}-0.020 \\
16(0.060)\end{array}$ & $\begin{array}{c}0.020 \\
(0.080)\end{array}$ & & & $\begin{array}{c}0.023 \\
(0.144)\end{array}$ & $\begin{array}{c}0.016 \\
(0.055)\end{array}$ & & \\
\hline Business situation April 2020 & $\begin{array}{l}-0.095 \\
(0.080)\end{array}$ & $\begin{array}{l}-0.068 \\
(0.072)\end{array}$ & & & $\begin{array}{l}-0.002 \\
(0.116)\end{array}$ & $\begin{array}{l}-0.039 \\
(0.062)\end{array}$ & & \\
\hline Business situation peak & $\begin{array}{c}0.023 \\
(0.071)\end{array}$ & $\begin{array}{l}-0.011 \\
(0.069)\end{array}$ & & & $\begin{array}{l}-0.039 \\
(0.117)\end{array}$ & $\begin{array}{l}-0.025 \\
(0.052)\end{array}$ & & \\
\hline Diff. 2019 and April 2020 & & & $\begin{array}{c}0.049 \\
(0.043)\end{array}$ & $\begin{array}{l}0.068^{*} \\
(0.036)\end{array}$ & & & $\begin{array}{c}0.040 \\
(0.076)\end{array}$ & $\begin{array}{c}0.052 \\
(0.034)\end{array}$ \\
\hline Diff. April 2020 and peak & & & $\begin{array}{l}-0.019 \\
(0.075)\end{array}$ & $\begin{array}{c}0.008 \\
(0.073)\end{array}$ & & & $\begin{array}{c}0.042 \\
(0.114)\end{array}$ & $\begin{array}{c}0.025 \\
(0.053)\end{array}$ \\
\hline Obs. & 60 & 70 & 60 & 70 & 42 & 88 & 42 & 88 \\
\hline Adj. $R^{2}$ & 0.494 & 0.379 & 0.467 & 0.373 & 0.541 & 0.527 & 0.54 & 0.522 \\
\hline
\end{tabular}

Notes: Linear probability model. Sector fixed effects, survey time fixed effects, and MNE fixed effects. Sample split into service sectors and industry (manufacturing) in columns (1)-(4), sample split into small firms (less than 50 employees) and big firms (more than 50 employees) in columns (5)-(8). Robust standard errors clustered at the sector level in parenthesis. $* * * *$, and $*$ denote statistical significance at the $1 \%, 5 \%$, and $10 \%$ level, respectively.

The take up of the Swiss short-time work program by firms is not very different for small and big firms, which is consistent with the findings in Table 5. The probability to use shorttime work raises only for firms in the service sector if the drop in the business situation between 2019 and April 2020 is greater. 